\title{
Contrasting chemical environments in summertime for atmospheric ozone across major Chinese industrial regions: the effectiveness of emission control strategies
}

\author{
Zhenze Liu $^{1}$, Ruth M. Doherty ${ }^{1}$, Oliver Wild ${ }^{2}$, Michael Hollaway ${ }^{2, a}$, and Fiona M. O'Connor ${ }^{3}$ \\ ${ }^{1}$ School of GeoSciences, The University of Edinburgh, Edinburgh, UK \\ ${ }^{2}$ Lancaster Environment Centre, Lancaster University, Lancaster, UK \\ ${ }^{3}$ Met Office Hadley Centre, Exeter, UK \\ anow at: Centre for Ecology \& Hydrology, Lancaster Environment Centre, Lancaster, UK
}

Correspondence: Zhenze Liu (zhenze.liu@ed.ac.uk)

Received: 9 December 2020 - Discussion started: 8 February 2021

Revised: 12 June 2021 - Accepted: 17 June 2021 - Published: 14 July 2021

\begin{abstract}
The United Kingdom Chemistry and Aerosols (UKCA) chemistry-climate model is used to quantify the differences in chemical environment for surface $\mathrm{O}_{3}$ for six major industrial regions across China in summer 2016. We first enhance the UKCA gas-phase chemistry scheme by incorporating reactive volatile organic compound (VOC) tracers that are necessary to represent urban and regional-scale $\mathrm{O}_{3}$ photochemistry. We demonstrate that the model with the improved chemistry scheme captures the observed magnitudes and diurnal patterns of surface $\mathrm{O}_{3}$ concentrations across these regions well. Simulated $\mathrm{O}_{3}$ concentrations are highest in Beijing and Shijiazhuang on the North China Plain and in Chongqing, lower in Shanghai and Nanjing in the Yangtze River Delta, and lowest in Guangzhou in the Pearl River Delta despite the highest daytime $\mathrm{O}_{3}$ production rates in Guangzhou. $\mathrm{NO}_{x} / \mathrm{VOC}$ and $\mathrm{H}_{2} \mathrm{O}_{2} / \mathrm{HNO}_{3}$ ratios indicate that $\mathrm{O}_{3}$ production across all regions except Chongqing is VOC limited. We confirm this by constructing $\mathrm{O}_{3}$ response surfaces for each region changing $\mathrm{NO}_{x}$ and VOC emissions and further contrast the effectiveness of measures to reduce surface $\mathrm{O}_{3}$ concentrations. In VOC-limited regions, reducing $\mathrm{NO}_{x}$ emissions by $20 \%$ leads to a substantial $\mathrm{O}_{3}$ increase $(11 \%)$ in Shanghai. We find that reductions in $\mathrm{NO}_{x}$ emissions alone of more than $70 \%$ are required to decrease $\mathrm{O}_{3}$ concentrations across all regions. Reductions in VOC emissions alone of $20 \%$ produce the largest decrease $(-11 \%)$ in $\mathrm{O}_{3}$ levels in Shanghai and Guangzhou and the smallest decrease $(-1 \%)$ in Chongqing. These responses are substan-
\end{abstract}

tially different from those currently found in highly populated regions in other parts of the world, likely due to higher $\mathrm{NO}_{x}$ emission levels in these Chinese regions. Our work provides an assessment of the effectiveness of emission control strategies to mitigate surface $\mathrm{O}_{3}$ pollution in these major industrial regions and emphasises that combined $\mathrm{NO}_{x}$ and VOC emission controls play a pivotal role in effectively offsetting high $\mathrm{O}_{3}$ levels. It also demonstrates new capabilities in capturing regional air pollution that will permit this model to be used for future studies of regional air-quality-climate interactions.

\section{Introduction}

Surface ozone $\left(\mathrm{O}_{3}\right)$ has become the main cause of atmospheric pollution in the summertime in China since 2013 and is particularly severe in industrial areas of China such as the North China Plain (NCP), the Yangtze River Delta (YRD), the Pearl River Delta (PRD) and the Sichuan Basin where precursor emissions are high (Li et al., 2019a). The 90th percentile of the maximum daily $8 \mathrm{~h}$ average (MDA8) $\mathrm{O}_{3}$ concentration in 30 of 74 major cities of China exceeded the National Ambient Air Quality Standard (100 ppb) in the summer of 2017 (Wang et al., 2017; Lu et al., 2018; Silver et al., 2018; Li et al., 2019b; H. X. Lu et al., 2019). During 20132017, the national Air Pollution Prevention and Control Action Plan successfully reduced emissions of fine particulate 
matter $\left(\mathrm{PM}_{2.5}\right)$ and nitrogen oxides $\left(\mathrm{NO}_{x}=\mathrm{NO}+\mathrm{NO}_{2}\right)$ in China by $33 \%$ and $21 \%$, respectively (Zheng et al., 2018). However, the reduction in $\mathrm{NO}_{x}$ emissions has led to an increase in $\mathrm{O}_{3}$ levels in polluted areas due to the non-linear chemistry of $\mathrm{O}_{3}$ and reduced titration of $\mathrm{O}_{3}$ by $\mathrm{NO}(\mathrm{Li}$ et al., 2019a; Wang et al., 2019). Volatile organic compounds (VOCs) are also important $\mathrm{O}_{3}$ precursors, and emissions of these have increased across China over the same period, exacerbating $\mathrm{O}_{3}$ pollution (Zheng et al., 2018). VOC emissions are believed to have decreased in megacity regions such as Beijing (Cheng et al., 2019), but the resulting $\mathrm{O}_{3}$ decrease is likely to have been offset by the $\mathrm{O}_{3}$ increase due to reduced $\mathrm{NO}_{x}$ emissions. This poses a challenge to mitigate surface $\mathrm{O}_{3}$ pollution. Therefore, the balance of emission controls on $\mathrm{NO}_{x}$ and VOC is critical to decreasing $\mathrm{O}_{3}$ levels in these regions. Meteorological processes also affect $\mathrm{O}_{3}$ formation through temperature, humidity, clouds, precipitation and biogenic emissions, and a number of papers have studied meteorological impacts on $\mathrm{O}_{3}$ over China (Gong and Liao, 2019; Liu and Wang, 2020; Shi et al., 2020). However, emission controls are the primary strategies used to reduce $\mathrm{O}_{3}$ pollution, and we focus on these for this study, as their effectiveness for different regions has not been fully investigated.

$\mathrm{O}_{3}$ is a secondary photochemical pollutant in the troposphere that can be produced rapidly through oxidation of its precursors $\mathrm{NO}_{x}$, VOCs and carbon monoxide $(\mathrm{CO})$ in the presence of sunlight. Power plants, industry, residences and transport are the main anthropogenic sources of $\mathrm{NO}_{x}$ and VOC emissions (Monks et al., 2015; M. Li et al., 2018). Isoprene is the principal biogenic VOC and is released from trees, plants and crops (Sindelarova et al., 2014). $\mathrm{O}_{3}$ formation is mainly initiated through oxidation of VOC species by hydroxyl radicals $(\mathrm{OH})$. The resulting organic peroxy radicals $\left(\mathrm{RO}_{2}\right)$ and hydroperoxyl radicals $\left(\mathrm{HO}_{2}\right)$ can convert $\mathrm{NO}$ to $\mathrm{NO}_{2}$ without destroying $\mathrm{O}_{3} . \mathrm{O}_{3}$ is then created from the combination of $\mathrm{O}\left({ }^{3} \mathrm{P}\right)$ atoms, formed from photolysis of the resulting $\mathrm{NO}_{2}$ and oxygen $\left(\mathrm{O}_{2}\right)$ (Sillman, 1999; von Schneidemesser et al., 2015; Wang et al., 2017). Under low- $\mathrm{NO}_{x}$ conditions, $\mathrm{HO}_{2}$ radicals may combine to produce hydrogen peroxide $\left(\mathrm{H}_{2} \mathrm{O}_{2}\right)$. However, at high $\mathrm{NO}_{x}$ concentrations, nitric acid $\left(\mathrm{HNO}_{3}\right)$, peroxy nitrates $\left(\mathrm{RO}_{2} \mathrm{NO}_{2}\right)$ and organic nitrates $\left(\mathrm{RONO}_{2}\right)$ are easily formed as $\mathrm{NO}_{x}$ reacts with $\mathrm{OH}$ and $\mathrm{RO}_{2}$. These species are the main sinks of radicals and $\mathrm{NO}_{x}$ and are readily removed from the atmosphere by deposition or exported to remote areas (Horowitz et al., 1998). Therefore, increasing $\mathrm{NO}_{x}$ concentrations increase $\mathrm{O}_{3}$ production but also accelerate the formation of $\mathrm{NO}_{x}$ sinks, leading to less efficient $\mathrm{O}_{3}$ formation. In addition, direct titration of $\mathrm{O}_{3}$ by $\mathrm{NO}$ becomes increasingly important at higher levels of $\mathrm{NO}_{x}$. There is hence a transition in the magnitude of $\mathrm{O}_{3}$ production from low- to high- $\mathrm{NO}_{x}$ conditions. This turnover is dependent on the local chemical environment and in particular on the relative abundance of $\mathrm{NO}_{x}$ and VOCs (Sillman, 1995; Kleinman et al., 1997; Thornton et al., 2002; Kleinman et al., 2005; Sillman and West, 2009).
A variety of $\mathrm{O}_{3}$ sensitivity indicators have been proposed to characterise the $\mathrm{O}_{3}$ response to changing precursor emissions. The simplest of these are based on the concentration ratios of the precursors, $\mathrm{NO}_{x} / \mathrm{VOCs}$, or of their oxidation products, $\mathrm{H}_{2} \mathrm{O}_{2} / \mathrm{HNO}_{3}$ (Sillman, 1995). $\mathrm{O}_{3}$ concentrations increase with $\mathrm{NO}_{x}$ emissions and are not sensitive to VOC emissions in a $\mathrm{NO}_{x}$-limited regime when $\mathrm{NO}_{x}$ concentrations are relatively low (Sillman et al., 1990). However, in a VOC-limited regime, $\mathrm{O}_{3}$ levels may increase with decreasing $\mathrm{NO}_{x}$ emissions, which is common in urban areas with high $\mathrm{NO}_{x}$ emissions, and this is reflected in high $\mathrm{NO}_{x} / \mathrm{VOC}$ or low $\mathrm{H}_{2} \mathrm{O}_{2} / \mathrm{HNO}_{3}$ ratios. Critical values of these indicators of $\mathrm{O}_{3}$ sensitivity vary by region and by season (Sillman, 1995; Liu et al., 2010; Xing et al., 2019). Most major industrial regions in China are believed to be VOC limited, and rural areas are $\mathrm{NO}_{x}$ limited or in a transition regime (Jin and Holloway, 2015; Wang et al., 2017). $\mathrm{O}_{3}$ production efficiency (OPE) is another important metric to evaluate the impacts of $\mathrm{NO}_{x}$ emissions on $\mathrm{O}_{3}$ concentrations (Liu et al., 1987; Kleinman et al., 2002). This is defined as the number of $\mathrm{O}_{3}$ molecules produced per molecule of $\mathrm{NO}_{x}$ oxidised. Low OPE values are typically associated with high- $\mathrm{NO}_{x}$ conditions and indicate that there is less $\mathrm{O}_{3}$ produced from a given amount of $\mathrm{NO}_{x}$. OPE values generally increase as $\mathrm{NO}_{x}$ emissions decrease, reflecting greater $\mathrm{O}_{3}$ production per molecule of $\mathrm{NO}_{x}$ oxidised at lower $\mathrm{NO}_{x}$ levels.

In this study, we develop new capabilities in a global-scale model by incorporating higher-VOC chemistry, allowing the model to represent the oxidation environment in major industrialised regions in China. We focus on the spatial and temporal variation of daytime $\mathrm{O}_{3}$ in this study. We first evaluate the performance of this global chemistry-climate model in simulating regional $\mathrm{O}_{3}$ across large industrialised regions. We use $\mathrm{O}_{3}$ sensitivity indicators to compare and contrast the chemical oxidative environment across these different regions in China to identify emission control measures that would be most beneficial to reduce $\mathrm{O}_{3}$ pollution levels. Using a global model novelly allows us to compare the impact of emission control measures in China with those in other major industrialised regions across the world. The value of this approach is that the same model set-up can be used to assess the impact of future emission and climate scenarios, studies of tropospheric and stratospheric $\mathrm{O}_{3}$ influences, and comparisons of $\mathrm{O}_{3}$ in different parts of world.

The configuration of the model used in this study is described in Sect. 2, along with its development and application to surface $\mathrm{O}_{3}$ in China. We evaluate the model performance in reproducing the diurnal cycles of surface $\mathrm{O}_{3}$ and $\mathrm{NO}_{2}$ in Sect. 3, and we investigate the $\mathrm{O}_{3}$ chemical environment in China, including $\mathrm{O}_{3}$ precursor concentrations and sensitivity ratios in Sect. 4. We calculate the local $\mathrm{O}_{3}$ production rates, $\mathrm{O}_{3}$ loss rates, $\mathrm{NO}_{x}$ loss rates and OPE in Sect. 5. We then quantify the $\mathrm{O}_{3}$ responses to changing $\mathrm{NO}_{x}$ and $\mathrm{VOC}$ emissions in these regions and investigate the requirements of emission controls to reduce $\mathrm{O}_{3}$ levels in each region in 
Sects. 6 and 7. To provide a global context we compare and contrast the effectiveness of emission control strategies with that in other parts of the world in Sect. 7 and present our conclusions in Sect. 8.

\section{Materials and methods}

\subsection{Model description, development and application}

The United Kingdom Chemistry and Aerosols (UKCA) model is a state-of-the-art chemistry and aerosol model that simulates atmospheric composition from the troposphere to the upper stratosphere. It is coupled to the Met Office Hadley Centre's Global Environment Model (HadGEM) family of climate models, all of which are based on the UK Unified Model (MetUM) (O'Connor et al., 2014). It is also the atmospheric composition component of the UK Earth System Model (UKESM) (Sellar et al., 2019). Version 10.6.1 of UKCA is used in this study, coupled with the Global Atmosphere 7.1 (GA7.1) configuration (Walters et al., 2019) of HadGEM3 (Hewitt et al., 2011). The spatial resolution is N96L 85 with $1.875^{\circ}$ by longitude and $1.25^{\circ}$ by latitude, and there are 85 terrain-following hybrid height layers with a model top at $85 \mathrm{~km}$. The model time step is $20 \mathrm{~min}$ for meteorology, and chemistry is calculated every hour. Wind speed and temperature are nudged with ERA-Interim reanalyses from the European Centre for Medium-Range Weather Forecasts (ECMWF) every $6 \mathrm{~h}$ (Dee et al., 2011). Sea surface temperature and sea ice fields are prescribed with the climatology mean of 1995-2004 (Reynolds et al., 2007).

The stratosphere-troposphere (Strat-Trop) gas-phase chemical scheme is used to simulate the inorganic odd oxygen $\left(\mathrm{O}_{x}\right)$, hydrogen $\left(\mathrm{HO}_{x}=\mathrm{OH}+\mathrm{HO}_{2}\right)$, and $\mathrm{NO}_{x}$ chemical cycles; oxidation of $\mathrm{CO}$ and VOCs; chlorine and bromine chemistry; and heterogeneous processes on aerosols (Archibald et al., 2020). The Global Model of Aerosol Processes (GLOMAP) aerosol scheme is used with a two-moment pseudo-modal aerosol dynamics approach to simulate sulfate, sea salt, dust, black carbon, and both primary and secondary organic aerosol (Mann et al., 2010). Interactive photolysis is represented with Fast-JX, which derives photolysis rates between 177 and $750 \mathrm{~nm}$ (Neu et al., 2007).

Global chemistry-climate models typically include simplified gas-phase chemistry schemes representing a limited number of species to mitigate high computational demands. Major long-lived VOC species are selected, and more reactive VOC species are typically omitted from the chemistry scheme (Young et al., 2018). Eight discrete emitted VOC species - formaldehyde (HCHO), ethane $\left(\mathrm{C}_{2} \mathrm{H}_{6}\right)$, propane $\left(\mathrm{C}_{3} \mathrm{H}_{8}\right)$, acetaldehyde $\left(\mathrm{CH}_{3} \mathrm{CHO}\right)$, acetone $\left(\left(\mathrm{CH}_{3}\right)_{2} \mathrm{CO}\right)$, methanol $\left(\mathrm{CH}_{3} \mathrm{OH}\right)$, isoprene $\left(\mathrm{C}_{5} \mathrm{H}_{8}\right)$ and monoterpene $\left(\mathrm{C}_{10} \mathrm{H}_{16}\right)$ - are simulated in the Strat-Trop chemistry scheme of UKCA. This selection is appropriate for simulating the global burden of $\mathrm{O}_{3}$ but is less suitable for simulating $\mathrm{O}_{3}$ concentrations in high-emission areas. In industrial regions of China, large abundances of more reactive VOCs such as alkenes and aromatics make substantial contributions to $\mathrm{O}_{3}$ production (Wu and Xie, 2017; Tan et al., 2019; Liu et al., 2020). To address this, we incorporate more reactive classes of VOC including alkenes, higher alkanes and aromatics, represented by propene $\left(\mathrm{C}_{3} \mathrm{H}_{6}\right)$, butane $\left(\mathrm{C}_{4} \mathrm{H}_{10}\right)$ and toluene $\left(\mathrm{C}_{7} \mathrm{H}_{8}\right)$ respectively in the chemistry scheme (Atkinson et al., 2006; Folberth et al., 2006). This permits a more realistic simulation of photochemically active environments and allows rapid $\mathrm{O}_{3}$ formation in high-VOC-emission regions to be captured. The improved chemistry scheme includes 101 species, 244 bimolecular reactions, 26 uni- and termolecular reactions, 70 photolytic reactions, 5 heterogeneous reactions, and 3 aqueous-phase reactions for the sulfur cycle.

We perform model simulations for 2016 and focus our results on summer (June-July-August, JJA). We spin up the model for 4 months and then simulate the full year nudged with ERA-Interim reanalysis data for 2016. The new capabilities of the model allow us to investigate regional $\mathrm{O}_{3}$ chemical environment in industrial regions of China in the model. The relatively coarse resolution of the model may lead to biases in surface $\mathrm{O}_{3}$ associated with numerical diffusion (Wild and Prather, 2006; Stock et al., 2014; Fenech et al., 2018; Mertens et al., 2020), but we note that the lifetime of $\mathrm{O}_{3}$ makes it a regional-scale pollutant except very close to high-emission sources (Valari and Menut, 2008; Hodnebrog et al., 2011; Biggart et al., 2020). This study demonstrates the first application of this improved chemistry scheme to high-emission regions worldwide and lays the foundation for more detailed studies of the interactions between air quality and climate in a global chemistry-climate model under future scenarios.

\subsection{Emissions}

The anthropogenic emission inventory of Hemispheric Transport of Air Pollution (HTAP) for 2010 is used for the globe outside China (Janssens-Maenhout et al., 2015). The Multi-resolution Emission Inventory for China (MEIC) is used to provide emissions over China for 2013 ( $\mathrm{Li}$ et al., 2017). We apply independent diurnal and vertical profiles to each emission sector (industry, power plants, transport and residences) according to European Monitoring and Evaluation Programme (EMEP) emissions (Bieser et al., 2011; Mailler et al., 2013). Biogenic VOC (BVOC) emissions are calculated interactively through the Joint UK Land Environment Simulator (JULES) land-surface scheme in UKCA (Pacifico et al., 2011). The Global Fire Emissions Database (GFED4) is used for biomass burning emissions (van der Werf et al., 2010). Other aspects of the emissions used are as described in Archibald et al. (2020). 
Table 1. Number of measurement sites and grid cells in the six industrial regions.

\begin{tabular}{lrr}
\hline Region & $\begin{array}{r}\text { No. of } \\
\text { measurement sites }\end{array}$ & $\begin{array}{r}\text { No. of } \\
\text { grid cells }\end{array}$ \\
\hline Beijing & 46 & 4 \\
Shijiazhuang & 28 & 2 \\
Shanghai & 58 & 2 \\
Nanjing & 45 & 1 \\
Guangzhou & 45 & 1 \\
Chongqing & 25 & 1 \\
\hline
\end{tabular}

Given the rapid changes in anthropogenic emissions across China, we adjust $\mathrm{NO}_{x}$, VOCs, $\mathrm{CO}$, sulfur dioxide $\left(\mathrm{SO}_{2}\right)$, black carbon (BC) and organic carbon (OC) emissions in MEIC from 2013 to 2016 by applying national and urban emission scaling factors. $\mathrm{NO}_{x}$ emissions decreased by $18.8 \%$, and VOC emissions increased slightly by $1.1 \%$ between 2013 and 2016 across China (Zheng et al., 2018). $\mathrm{NO}_{x}$ and VOC emissions are estimated to have decreased by $24.2 \%$ and $12.8 \%$ respectively in Beijing and surrounding areas between 2013 and 2016 (Cheng et al., 2019). We apply the Beijing scaling factors to major industrialised regions, reflecting tighter emission controls in these developed urban regions, and use national scaling factors across the rest of the country.

\subsection{Selected regions and observations}

We focus on six heavily populated regions with high emissions within the major industrialised regions in China. These include Beijing and Shijiazhuang on the North China Plain (32-40 $\left.\mathrm{N}, 114-121^{\circ} \mathrm{E}\right)$, Shanghai and Nanjing in the Yangtze River Delta $\left(28-33^{\circ} \mathrm{N}, 118-123^{\circ} \mathrm{E}\right)$, Guangzhou in the Pearl River Delta $\left(21-25^{\circ} \mathrm{N}, 111-115^{\circ} \mathrm{E}\right)$, and Chongqing in the Sichuan Basin $\left(28-32^{\circ} \mathrm{N}, 103-108^{\circ} \mathrm{E}\right)$; see Fig. 1. Anthropogenic $\mathrm{NO}_{x}$ and VOC emissions are high in these regions (Fig. 2) due to rapid industrialisation, urbanisation and socio-economic development. Model grid cells that include observation stations located in each of the urban and rural regions are selected to be representative of these regions; see Table 1. For comparison with observations, we calculate a grid-weighted mean according to the number of measurement sites in each model grid cell for the region.

We use observed hourly concentrations of air pollutants including $\mathrm{O}_{3}$ and $\mathrm{NO}_{2}$ from the surface monitoring networks of China, obtained from the public website https://quotsoft. net/air/ (last access: 22 October 2020), which mirrors data from the Chinese National Environmental Monitoring Centre (CNEMC) http://www.cnemc.cn/ (last access: 22 October 2020). A total of 450 measurement stations in China started operating in 2013, growing rapidly to 1670 stations by 2019 .

\section{Model evaluation of surface $\mathrm{O}_{3}$ and $\mathrm{NO}_{2}$}

We evaluate the diurnal variation in simulated surface $\mathrm{O}_{3}$ and $\mathrm{NO}_{2}$ concentrations against summertime observations for JJA, 2016, for the six industrialised regions (Figs. 3, 4). In general, the diurnal variation of observed $\mathrm{O}_{3}$ is matched relatively well, and the correlation coefficients are relatively high; see Table 2. Mean concentrations for $\mathrm{O}_{3}$ and $\mathrm{NO}_{2}$ over the lowest three model layers (from the surface up to $130 \mathrm{~m})$ are also compared with observations. In the daytime, differences between the surface and three lowest layers are small due to efficient mixing in the planetary boundary layer (PBL). The height of the nocturnal PBL is typically underestimated in the model, leading to overestimated $\mathrm{NO}_{x}$ concentrations and hence underestimated $\mathrm{O}_{3}$ concentrations at nighttime due to excessive $\mathrm{O}_{3}$ titration by $\mathrm{NO}$ (André et al., 1978; Petersen et al., 2019; Zhao et al., 2019). Figure $3 \mathrm{a}$ shows a large difference in nighttime $\mathrm{O}_{3}$ concentrations across the three layers, reflecting stable conditions that allow $\mathrm{NO}_{x}$ to accumulate at the surface. Simulated surface $\mathrm{O}_{3}$ concentrations therefore tend to be underestimated at nighttime. In addition, nighttime heterogeneous uptake of nitrogen on aerosols remains highly uncertain due to the complexity in estimating uptake coefficients for different aerosol composition/mixing states (Lowe et al., 2015; Tham et al., 2018). In UKCA, the lack of nitrate aerosol in the aerosol scheme may result in a lower uptake of nitrogen (Archibald et al., 2020), particularly in regions with high $\mathrm{NO}_{x}$ emissions. Therefore, there may be a bias in the heterogeneous removal of nitrogen, potentially leading to higher $\mathrm{NO}_{2}$ and lower $\mathrm{O}_{3}$ concentrations at nighttime. In contrast, the peaks in daytime $\mathrm{O}_{3}$ concentrations are captured relatively well, reflecting efficient $\mathrm{O}_{3}$ production in the high-VOC environment.

Daily mean $\mathrm{O}_{3}$ concentrations for Beijing, Shijiazhuang, Shanghai and Guangzhou are reproduced well with relatively small biases $(\sim 10 \%$; see Table 2$)$. Simulated daily mean $\mathrm{O}_{3}$ concentrations are highest ( $>40 \mathrm{ppb}$ ) for Beijing, Shijiazhuang and Chongqing; lower in Shanghai and Nanjing ( $<40 \mathrm{ppb}$ ); and lowest for Guangzhou ( $30 \mathrm{ppb})$. Although daily mean $\mathrm{O}_{3}$ concentrations are captured relatively well, as seen in Figs. 3a and 4a, daytime maximum $\mathrm{O}_{3}$ concentrations are overestimated, associated with underestimated $\mathrm{NO}_{2}$ concentrations. This overestimation is largest in Shijiazhuang, where the underestimation of daytime $\mathrm{NO}_{2}$ concentrations is larger than other regions. We find that there is a systematic bias in Chongqing, where simulated $\mathrm{O}_{3}$ levels are higher than observations. Chongqing is a mountainous inland region with complex topography that cannot be fully resolved, and surface $\mathrm{O}_{3}$ here is thus representative of higher surface altitudes leading to a systematic bias high compared with observations (Su et al., 2018) and a corresponding bias low for $\mathrm{NO}_{2}$ concentrations. In addition, simulated $\mathrm{O}_{3}$ increases from biogenic emissions in the Sichuan Basin are much larger in summertime than other regions (X. Lu et al., 2019), and uncer- 

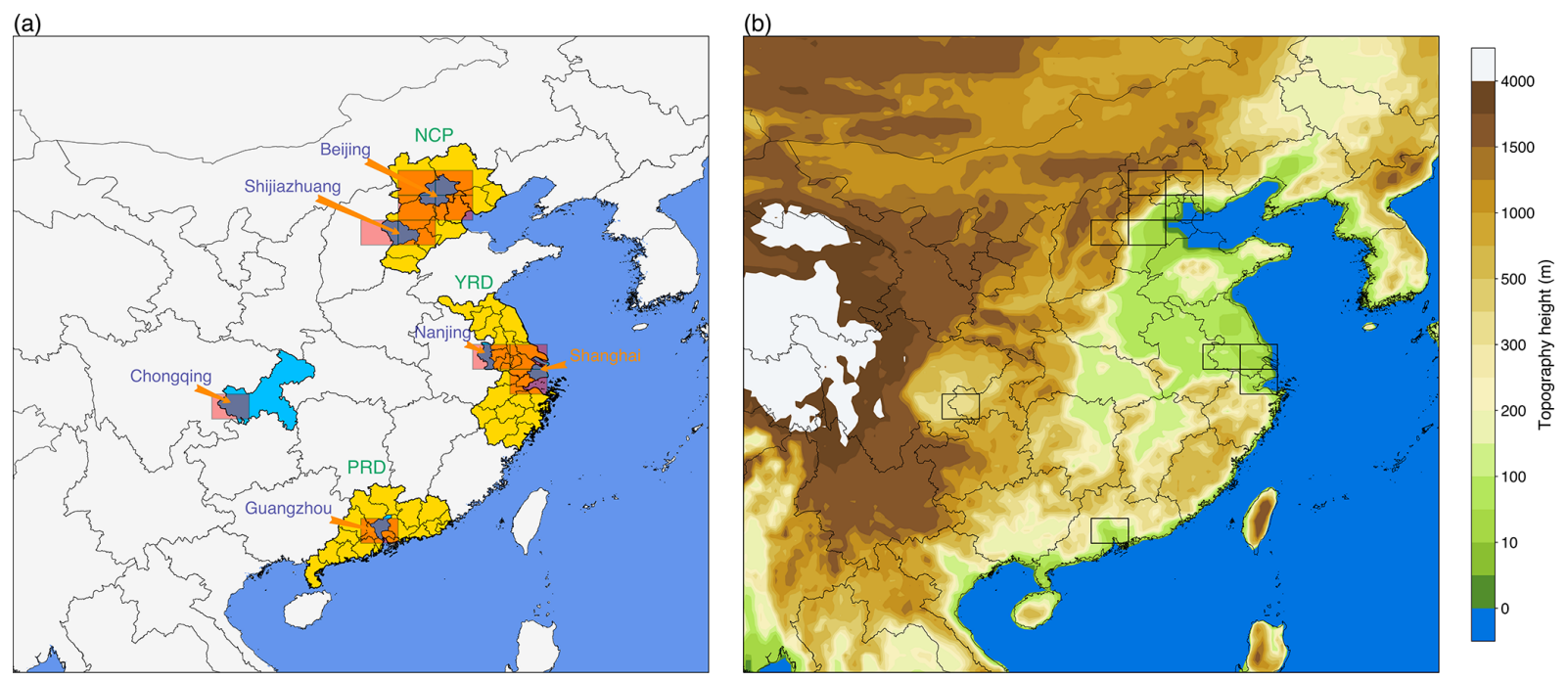

Figure 1. Map of China showing (a) the key provinces (yellow) representing the NCP, the YRD, and the PRD and locations of the six regions (blue) - Beijing, Shijiazhuang, Shanghai, Nanjing, Guangzhou and Chongqing - and UKCA model grid cells co-located with these regions (red); and (b) elevations across the whole of China.
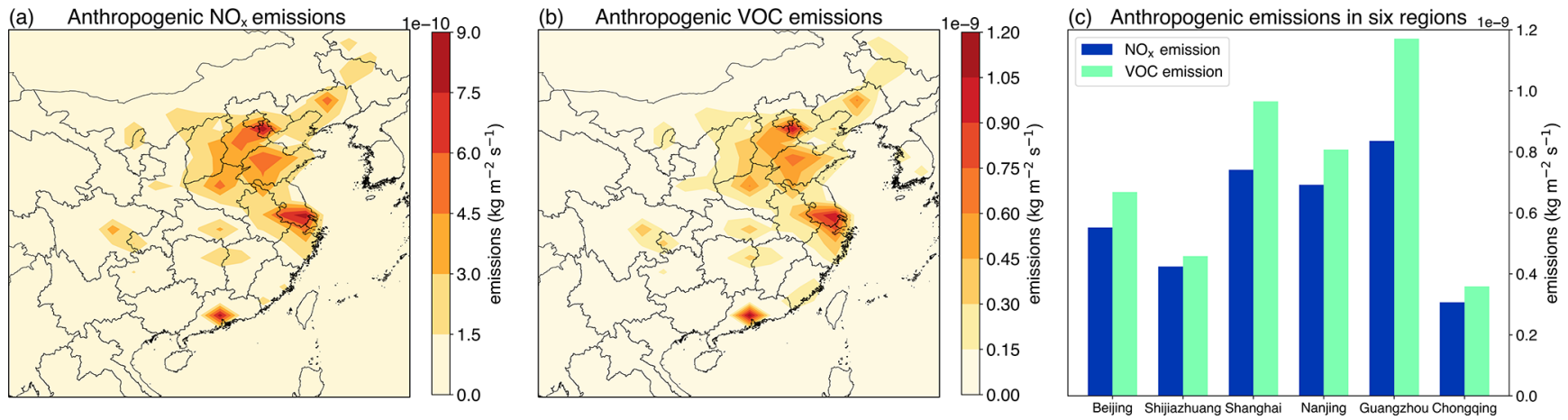

Figure 2. Spatial distributions of anthropogenic $\mathrm{NO}_{x}$ and VOC emissions $\left(\mathrm{kg} \mathrm{m}^{-2} \mathrm{~s}^{-1}\right)$ across China (a, b) and grid-weighted averaged emissions for the six regions within the four major industrialised regions (c) in JJA, 2016.

tainty in these emissions may contribute to the biases. Given our use of reliable meteorological reanalysis data, we note that meteorology is not the main influence on the model biases. We therefore investigate $\mathrm{O}_{3}$ chemical environments in different regions to explore regional differences below.

The diurnal patterns in $\mathrm{NO}_{2}$ concentrations can also be captured as reflected by high levels at nighttime and low levels in the daytime for all regions. Daytime $\mathrm{NO}_{2}$ concentrations can be reproduced relatively well, with a small underestimation. This underestimation may lead to overestimated $\mathrm{O}_{3}$ concentrations in a VOC-limited regime and underestimated $\mathrm{O}_{3}$ in a $\mathrm{NO}_{x}$-limited regime. While underestimated $\mathrm{NO}_{x}$ concentrations may reflect underestimated $\mathrm{NO}_{x}$ emissions, it is more likely to arise from the effects of dilution on $\mathrm{NO}_{x}$. High emissions in these regions are diluted over a large grid cell, resulting in lower $\mathrm{NO}_{2}$ concentrations in the daytime. This is offset by high $\mathrm{NO}_{2}$ concentrations in the $\mathrm{PBL}$ at nighttime as discussed above. The diurnal variation of $\mathrm{NO}_{2}$ concentrations is hence stronger in the simulations than the observations (Fig. 4a).

Figures 3 and 4 also show the frequency distribution of observed and modelled hourly $\mathrm{O}_{3}$ and $\mathrm{NO}_{2}$ concentrations. The simulated peaks in the distributions of $\mathrm{O}_{3}$ and $\mathrm{NO}_{2}$ are underestimated compared to observations for all six regions, reflecting the larger diurnal variation in the simulations. The diurnal variation is more closely simulated for $\mathrm{O}_{3}$ concentrations (correlation coefficient $r>0.7$ ) than for $\mathrm{NO}_{2}$ concentrations. The Chongqing region has the closest correlation with observations $(r=0.83)$, which provides evidence that the overestimation of $\mathrm{O}_{3}$ is systematic as suggested earlier. Overall, the magnitudes (see Table 2) and diurnal patterns (see Figs. 3 and 4) of both species can be simulated reasonably well, with differences between industrial regions clearly captured. 

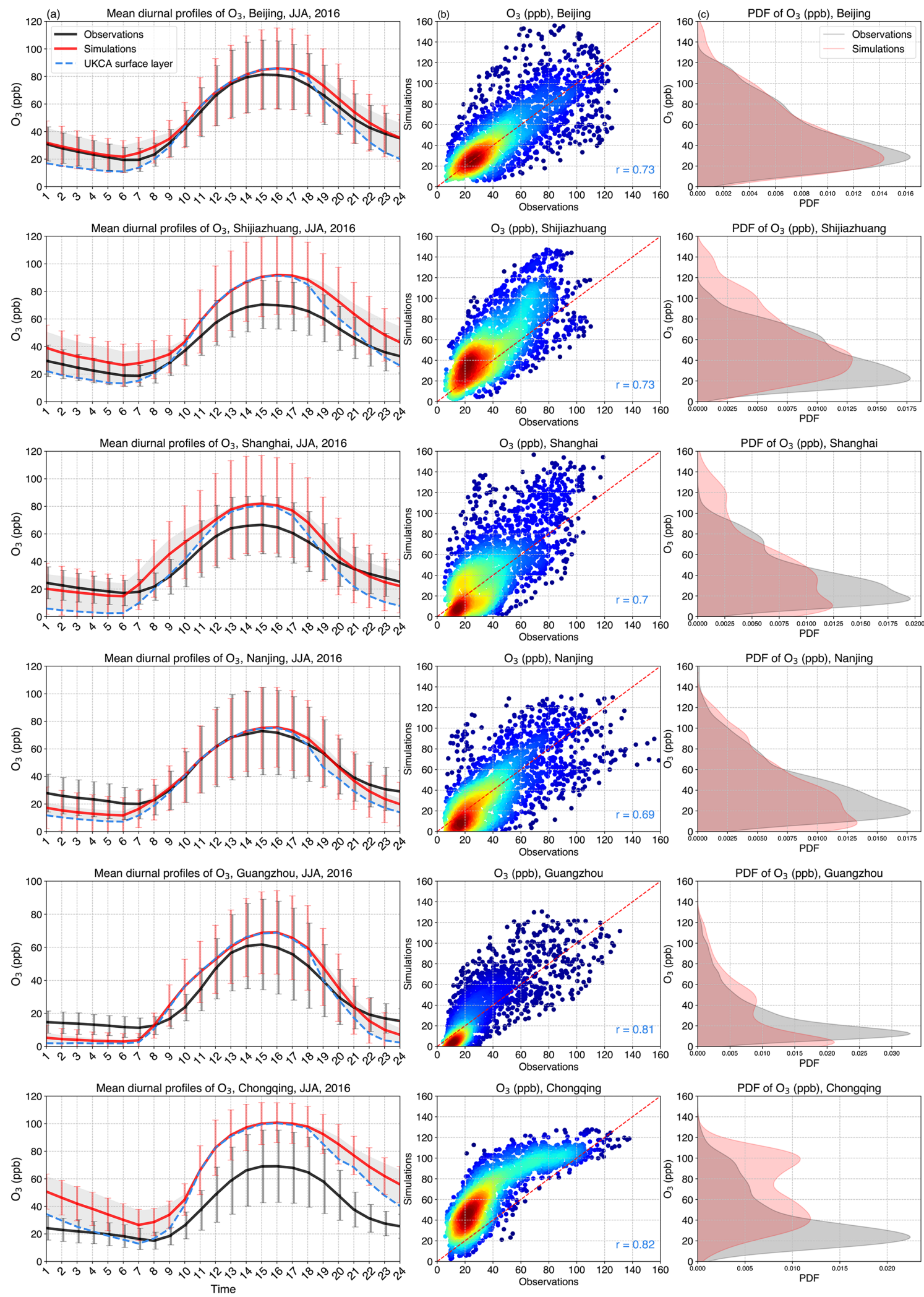

Figure 3. Comparison of observed and modelled $\mathrm{O}_{3}$ concentrations for the six industrialised regions in JJA, 2016, China. (a) Mean diurnal cycles of observed and modelled $\mathrm{O}_{3}$ concentrations (ppb). The shaded area represents the spread across the lowest three model layers. Error bars denote 1 standard deviation of hourly $\mathrm{O}_{3}$ concentrations across all days. (b) Observed and modelled hourly $\mathrm{O}_{3}$ concentrations (ppb; three lowest model layers) and correlation coefficient values $r$. (c) Probability density function (PDF) of $\mathrm{O}_{3}$ concentrations (ppb) for modelled and observed hourly values. 

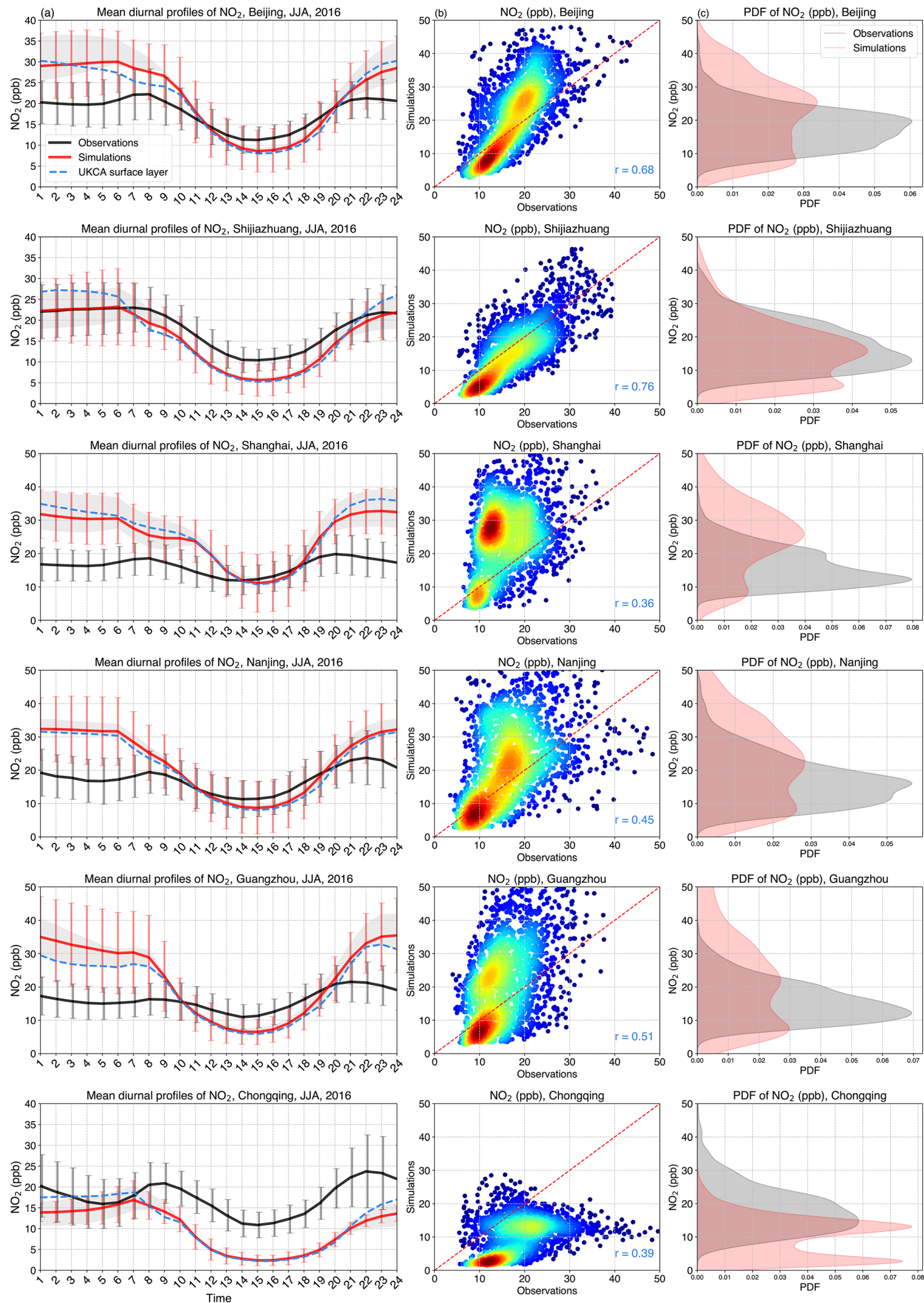

Figure 4. Comparison of observed and modelled $\mathrm{NO}_{2}$ concentrations for the six industrialised regions in JJA, 2016, China. (a) Mean diurnal cycles of observed and modelled $\mathrm{NO}_{2}$ concentrations (ppb). The shaded area represents the spread across the lowest three model layers. Error bars denote 1 standard deviation of hourly $\mathrm{NO}_{2}$ concentrations across all days. (b) Observed and modelled hourly $\mathrm{NO}_{2}$ concentrations (ppb; three lowest model layers) and correlation coefficient values $r$. (c) PDF of $\mathrm{NO}_{2}$ concentrations (ppb) for modelled and observed hourly values. 
Table 2. Comparison of modelled and observed daily mean surface $\mathrm{O}_{3}$ and $\mathrm{NO}_{2}$ concentrations for the six industrial regions in JJA, 2016, China.

\begin{tabular}{lcrrrr}
\hline Region & Obs. (ppb) & Sim. $(\mathrm{ppb})$ & Bias ppb/\% & RMSE (ppb) & Correlation $r$ \\
\hline $\mathrm{O}_{3}$ & & & & & \\
\hline Beijing & $47.7 \pm 22.1$ & $43.4 \pm 27.7$ & $-4.4(9.1 \%)$ & 8.1 & 0.77 \\
Shijiazhuang & $42.9 \pm 18.4$ & $47.6 \pm 28.7$ & $4.7(10.9 \%)$ & 11.6 & 0.78 \\
Shanghai & $38.3 \pm 17.5$ & $34.4 \pm 28.8$ & $-3.9(10.2 \%)$ & 12.7 & 0.77 \\
Nanjing & $42.6 \pm 18.9$ & $35.9 \pm 24.9$ & $-6.8(15.8 \%)$ & 9.8 & 0.71 \\
Guangzhou & $29.8 \pm 18.3$ & $28.0 \pm 25.9$ & $-1.8(-6.1 \%)$ & 9.4 & 0.81 \\
Chongqing & $38.1 \pm 19.2$ & $56.0 \pm 31.3$ & $18.0(47.2 \%)$ & 22.3 & 0.83 \\
\hline NO 2 & & & & & \\
\hline Beijing & $17.8 \pm 3.7$ & $20.7 \pm 8.2$ & $2.9(16.2 \%)$ & 5.8 & 0.69 \\
Shijiazhuang & $18.1 \pm 4.7$ & $16.7 \pm 8.3$ & $-1.4(7.7 \%)$ & 4.3 & 0.76 \\
Shanghai & $16.3 \pm 2.3$ & $26.1 \pm 8.7$ & $9.8(60.0 \%)$ & 12.1 & 0.50 \\
Nanjing & $17.2 \pm 3.6$ & $21.3 \pm 9.0$ & $4.1(23.7 \%)$ & 7.8 & 0.49 \\
Guangzhou & $16.1 \pm 3.0$ & $19.9 \pm 9.3$ & $3.8(23.7 \%)$ & 8.4 & 0.55 \\
Chongqing & $17.4 \pm 3.8$ & $10.9 \pm 6.3$ & $-6.4(37.1 \%)$ & 8.0 & 0.43 \\
\hline
\end{tabular}

\section{Differences in chemical environment}

Spatial distributions of modelled daytime concentrations of $\mathrm{O}_{3}, \mathrm{NO}_{x}$, VOCs and $\mathrm{O}_{3}$ sensitivity ratios $\left(\mathrm{NO}_{x} /\right.$ VOCs and $\mathrm{H}_{2} \mathrm{O}_{2} / \mathrm{HNO}_{3}$ ) are shown in Fig. 5 to illustrate the differences in chemical environment for the six regions. We use the standard definition of the maximum daily average $8 \mathrm{~h}$ (MDA8) ozone metric and consider this same time period for other species, which we refer to hereafter as daytime concentrations. For the sensitivity ratio $\mathrm{NO}_{x} / \mathrm{VOCs}$, we consider the sum of anthropogenic and biogenic daytime VOC concentrations.

Figure 5a shows high daytime $\mathrm{O}_{3}$ levels ( $>80 \mathrm{ppb}$ ) across northern China, eastern China and the Sichuan Basin in JJA, 2016. $\mathrm{O}_{3}$ levels in the PRD $(\sim 40 \mathrm{ppb})$ are much lower despite high emissions, likely due to transport of clean air from the South China Sea associated with the East Asian summer monsoon (Zhao et al., 2010; S. Li et al., 2018). Areas with high anthropogenic $\mathrm{NO}_{x}$ and VOC concentrations generally coincide with high-emission regions (Figs. 2, $5 \mathrm{~b}, \mathrm{c})$. High daytime $\mathrm{NO}_{x}$ concentrations $(>12 \mathrm{ppb}$ ) are simulated in Beijing and Shijiazhuang, Shanghai, and Nanjing. Chongqing has the lowest $\mathrm{NO}_{x}$ concentrations of 3-6 ppb due to relatively low $\mathrm{NO}_{x}$ emissions. High anthropogenic daytime VOCs concentrations are simulated across the main industrial regions, in particular in Shanghai with the highest levels (> 12 ppb; Fig. 5c).

The distribution of biogenic VOC concentrations (including isoprene and methanol) differs from that of anthropogenic VOCs (Fig. 5c, d). There is a strong latitudinal gradient, reflecting differences in climate and the spatial distribution of vegetation ( $\mathrm{Li}$ et al., 2013). The highest biogenic VOC levels are simulated in south-eastern China where deciduous and mixed broadleaf trees are the main source of biogenic VOCs. The YRD, the PRD and the Sichuan Basin have higher biogenic VOC concentrations than the NCP. Chongqing has the highest biogenic VOC levels of the regions considered here. However, higher biogenic VOC levels are found south of China in Laos, Vietnam and Cambodia.

High $\mathrm{NO}_{x} / \mathrm{VOC}$ ratios and low $\mathrm{H}_{2} \mathrm{O}_{2} / \mathrm{HNO}_{3}$ ratios typically indicate $\mathrm{VOC}$-limited $\mathrm{O}_{3}$ production. The transition between VOC- and $\mathrm{NO}_{x}$-limited regimes is typically about 0.25 for the $\mathrm{NO}_{x} /$ VOC ratio and about 0.2 for the $\mathrm{H}_{2} \mathrm{O}_{2} / \mathrm{HNO}_{3}$ ratio (Liu et al., 2010; Xing et al., 2019). From these two thresholds for the $\mathrm{O}_{3}$ sensitivity ratios, it can be seen that VOC-limited regions cover most areas of the NCP, parts of the YRD including Shanghai and Nanjing, and Guangzhou in the PRD (Fig. 5e, f). All six regions except Chongqing have $\mathrm{NO}_{x} /$ VOCs ratios $\geq 0.6$ and $\mathrm{H}_{2} \mathrm{O}_{2} / \mathrm{HNO}_{3}$ ratios $\leq 0.18$ (Table 3). This suggests that these regions have a chemical environment that is strongly VOC limited. In addition, VOC-limited regimes shown by both indicators are quite similar, showing that these two $\mathrm{O}_{3}$ sensitivity ratios may be useful to directly diagnose different $\mathrm{O}_{3}$ sensitivity regimes in China. Regions with high $\mathrm{NO}_{x} / \mathrm{VOC}$ ratios and low $\mathrm{H}_{2} \mathrm{O}_{2} / \mathrm{HNO}_{3}$ ratios typically occur where $\mathrm{NO}_{x}$ concentrations are high. Overall, these transition values delineate the different $\mathrm{O}_{3}$ sensitivity regions across China well, showing VOC-limited regimes in the major industrial regions with high emissions. However, we note that these $\mathrm{O}_{3}$ sensitivity ratios only provide an estimate of the chemical environment, and further, more detailed investigation of $\mathrm{O}_{3}$ responses to emission changes is required. 

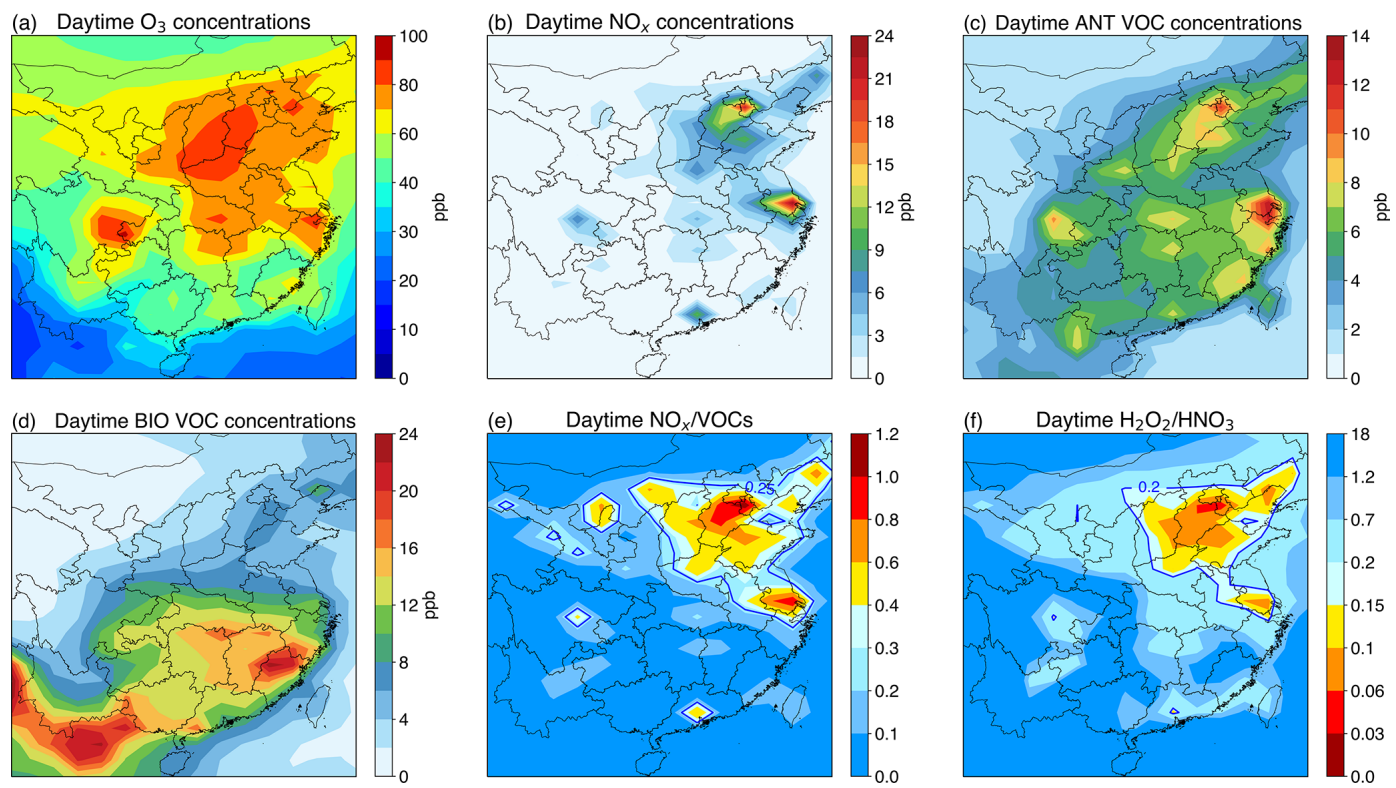

Figure 5. Spatial distributions of simulated surface daytime $\mathrm{O}_{3}, \mathrm{NO}_{x}$, anthropogenic VOCs, biogenic VOCs (ppb) (a-d), and two $\mathrm{O}_{3}$ sensitivity ratios $-\mathrm{NO}_{x} /$ VOCs and $\mathrm{H}_{2} \mathrm{O}_{2} / \mathrm{HNO}_{3}(\mathbf{e}, \mathbf{f})-$ in JJA, 2016, China.

Table 3. Simulated surface daytime concentrations of species, radicals, $\mathrm{O}_{3}$ sensitivity ratios and the photolysis rate $j\left(\mathrm{O}^{1} \mathrm{D}\right)$ for the six industrial regions in JJA, 2016, China.

\begin{tabular}{|c|c|c|c|c|c|c|}
\hline Region & Beijing & Shijiazhuang & Shanghai & Nanjing & Guangzhou & Chongqing \\
\hline \multicolumn{7}{|l|}{ Species (ppb) } \\
\hline $\mathrm{O}_{3}$ & 78.0 & 83.5 & 70.1 & 66.8 & 60.2 & 93.8 \\
\hline $\mathrm{NO}_{x}$ & 12.8 & 8.7 & 19.2 & 12.9 & 10.7 & 3.8 \\
\hline VOC (ANT) & 8.7 & 7.0 & 12.7 & 7.6 & 7.5 & 7.7 \\
\hline VOC (BIO) & 5.5 & 4.3 & 10.6 & 9.2 & 10.2 & 13.5 \\
\hline VOC (Total) & 14.3 & 11.3 & 23.3 & 16.9 & 17.7 & 21.3 \\
\hline \multicolumn{7}{|l|}{ Sensitivity ratios } \\
\hline $\mathrm{NO}_{x} / \mathrm{VOCs}$ & 0.79 & 0.73 & 0.89 & 0.78 & 0.60 & 0.18 \\
\hline $\mathrm{H}_{2} \mathrm{O}_{2} / \mathrm{HNO}_{3}$ & 0.18 & 0.08 & 0.10 & 0.11 & 0.09 & 0.29 \\
\hline \multicolumn{7}{|l|}{ Radicals } \\
\hline $\mathrm{OH} / 10^{6} \mathrm{~cm}^{-3}$ & 7.8 & 10.3 & 8.4 & 9.8 & 13.0 & 16.6 \\
\hline $\mathrm{HO}_{2} / 10^{8} \mathrm{~cm}^{-3}$ & 2.6 & 2.9 & 2.3 & 2.2 & 2.2 & 7.4 \\
\hline $\mathrm{RO}_{2} / 10^{8} \mathrm{~cm}^{-3}$ & 1.0 & 0.9 & 0.8 & 0.8 & 0.9 & 2.5 \\
\hline \multicolumn{7}{|l|}{ Photolysis rate } \\
\hline$j\left(\mathrm{O}^{1} \mathrm{D}\right) / 10^{-5} \mathrm{~s}^{-1}$ & 2.3 & 2.6 & 2.3 & 2.5 & 3.1 & 3.4 \\
\hline
\end{tabular}

\section{Differences in local $\mathrm{O}_{3}$ production rates}

In this section, we calculate the daytime production rates for surface $\mathrm{O}_{3}$ to investigate how the local $\mathrm{O}_{3}$ production compares across the six regions. We define the net $\mathrm{O}_{3}$ production rate $\left(\mathrm{ppb} \mathrm{h}^{-1}\right)$ as the gross rate of production of $\mathrm{O}_{3}, \mathrm{P}\left(\mathrm{O}_{3}\right)$, from the reactions $\mathrm{HO}_{2}+\mathrm{NO}$ and $\mathrm{RO}_{2}+\mathrm{NO}$ minus the gross rate of loss of $\mathrm{O}_{3}, \mathrm{~L}\left(\mathrm{O}_{3}\right)$, from the reactions $\mathrm{O}\left({ }^{1} \mathrm{D}\right)+\mathrm{H}_{2} \mathrm{O}$,
$\mathrm{O}_{3}+\mathrm{OH}, \mathrm{O}_{3}+\mathrm{HO}_{2}$ and $\mathrm{O}_{3}+$ VOCs. We assume that the pathways above represent the net $\mathrm{O}_{3}$ production rate under $\mathrm{O}_{3}$ photochemical steady state between $\mathrm{NO}$ and $\mathrm{NO}_{2}$, and they are shown as follows: 


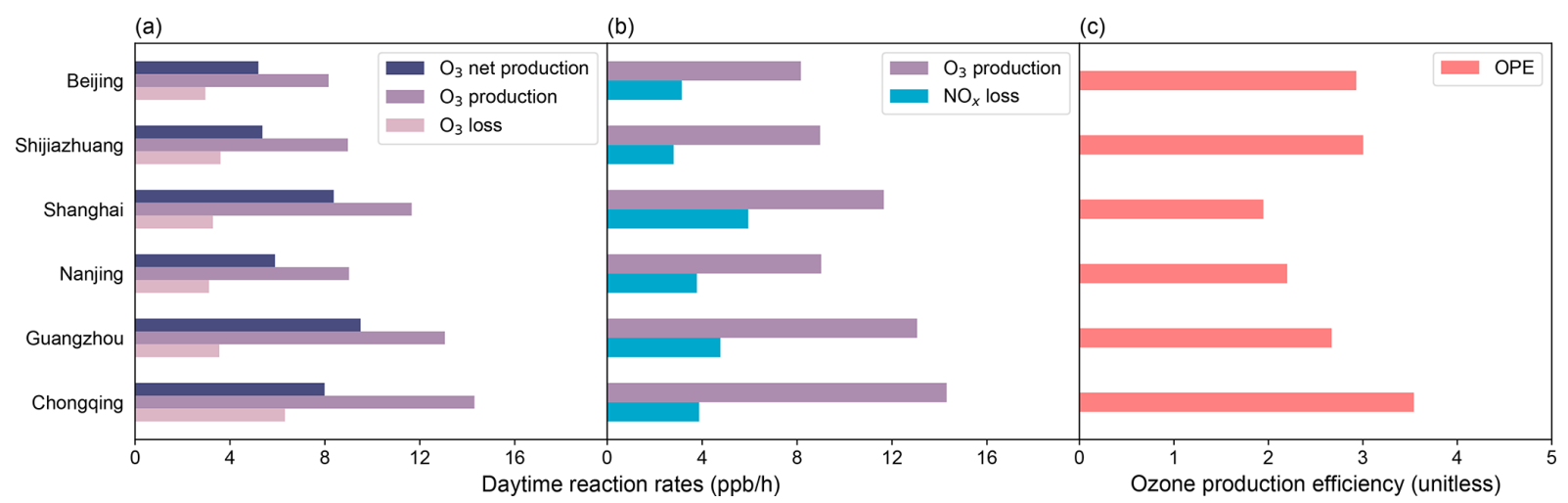

Figure 6. Simulated surface daytime (a) net $\mathrm{O}_{3}$ production rates, gross $\mathrm{O}_{3}$ production rates and gross $\mathrm{O}_{3}$ loss rates (ppb h ${ }^{-1}$ ); (b) gross $\mathrm{O}_{3}$ production rates and $\mathrm{NO}_{x}$ loss rates $\left(\mathrm{ppb} \mathrm{h}^{-1}\right)$; and (c) OPE (unitless) for the six industrial regions in JJA, 2016, China.

$$
\begin{aligned}
\text { Net } P\left(\mathrm{O}_{3}\right)= & P\left(\mathrm{O}_{3}\right)-L\left(\mathrm{O}_{3}\right) \\
= & k_{1}\left[\mathrm{HO}_{2}\right][\mathrm{NO}]+k_{2}\left[\mathrm{RO}_{2}\right][\mathrm{NO}] \\
& -\left(k_{3}\left[\mathrm{O}\left({ }^{1} \mathrm{D}\right)\right]\left[\mathrm{H}_{2} \mathrm{O}\right]+k_{4}\left[\mathrm{O}_{3}\right][\mathrm{OH}]\right. \\
& \left.+k_{5}\left[\mathrm{O}_{3}\right]\left[\mathrm{HO}_{2}\right]+k_{6}\left[\mathrm{O}_{3}\right][\mathrm{VOCs}]\right),
\end{aligned}
$$

where $k_{i}$ represents the rate coefficient of reaction $i$.

The loss of $\mathrm{NO}_{x}, \mathrm{~L}\left(\mathrm{NO}_{x}\right)$, is principally determined by the reactions $\mathrm{OH}+\mathrm{NO}_{2}, \mathrm{RO}_{2}+\mathrm{NO}_{2}$ and $\mathrm{RO}_{2}+\mathrm{NO}$, which produce $\mathrm{HNO}_{3}, \mathrm{RO}_{2} \mathrm{NO}_{2}$ and $\mathrm{RONO}_{2}$ respectively. OPE is then defined as the number of $\mathrm{O}_{3}$ molecules produced per molecule of $\mathrm{NO}_{x}$ consumed (Liu et al., 1987).

$\mathrm{OPE}=\frac{P\left(\mathrm{O}_{3}\right)}{L\left(\mathrm{NO}_{x}\right)}$

As shown in Fig. 6, local $\mathrm{O}_{3}$ production varies across the six regions, with $\mathrm{O}_{3}$ net production rates ranging from 4 to $10 \mathrm{ppbh}^{-1}$. Simulated daytime net $\mathrm{O}_{3}$ production rates are highest $\left(>8 \mathrm{pph}^{-1}\right)$ in Shanghai and Guangzhou mainly due to high precursor emissions, and this is reflected by higher $\mathrm{O}_{3}$ concentrations in Shanghai than in nearby Nanjing. While $\mathrm{O}_{3}$ production is high in Guangzhou, the $\mathrm{O}_{3}$ concentrations are much lower than in other regions, indicating that meteorological impacts in this coastal region are important to transport $\mathrm{O}_{3}$ produced locally. $\mathrm{O}_{3}$ net production in Beijing and Shijiazhuang is similar to that in Nanjing $\left(\sim 5 \mathrm{ppbh}^{-1}\right) . \mathrm{O}_{3}$ production in Chongqing is also high, reflecting high radical concentrations (see Table 3 ) that promote $\mathrm{O}_{3}$ production despite lower precursor emissions. High photolysis rates $j\left(\mathrm{O}\left({ }^{1} \mathrm{D}\right)\right)$ in Chongqing and Guangzhou contribute to high concentrations of $\mathrm{OH}$ radicals (Table 3 ). $\mathrm{O}_{3}$ destruction rates are fairly similar $\left(<4 \mathrm{ppbh}^{-1}\right)$ across these regions but are higher in Chongqing, offsetting its high $\mathrm{O}_{3}$ production rates.

The simulated $\mathrm{NO}_{x}$ loss rates (Fig. 6b) show the highest removal of $\mathrm{NO}_{x}$ in Shanghai, where $\mathrm{NO}_{x}$ concentrations are also highest. This influences OPE, which is strongly dependent on $\mathrm{NO}_{x}$ loss, and leads to the lowest OPE in Shanghai and highest in Chongqing (Fig. 6c). The low OPE in Shanghai and Nanjing shows the low efficiency in $\mathrm{O}_{3}$ production per molecule of $\mathrm{NO}_{x}$ consumed. However, the OPE values in all six regions are generally lower than those in other remote and rural regions, in agreement with Wang et al. (2018), indicating that high precursor emissions in these regions are the main cause of high surface $\mathrm{O}_{3}$ concentrations.

\section{Response of $\mathrm{O}_{3}$ to emission controls}

We quantify the response of daytime $\mathrm{O}_{3}$ to emission changes to investigate the relationship between the chemical environment and the magnitude of $\mathrm{O}_{3}$ changes for the six industrial regions of China. We implement three scenarios applying $20 \%$ reductions in anthropogenic $\mathrm{NO}_{x}$ emissions, VOC emissions, and combined $\mathrm{NO}_{x}$ and $\mathrm{VOC}$ emissions.

Spatial distributions of simulated daytime surface $\mathrm{O}_{3}$ responses vary across China (Fig. 7). In the $20 \% \mathrm{NO}_{x}$ emission control scenario, substantial $\mathrm{O}_{3}$ increases $(2-10 \mathrm{ppb})$ can be seen in the NCP, the YRD, and the PRD, and $\mathrm{O}_{3}$ concentrations decrease $(0-8 \mathrm{ppb})$ in the Sichuan Basin. In the $20 \%$ VOC emission control scenario, there are small $\mathrm{O}_{3}$ changes in most non-industrial regions of China $(-1-$ $2 \mathrm{ppb}$ ), but $\mathrm{O}_{3}$ concentrations generally decrease by $1-9 \mathrm{ppb}$ across the NCP, the YRD and the PRD. The Sichuan Basin shows relatively small $\mathrm{O}_{3}$ decreases. Areas showing $\mathrm{O}_{3}$ increases in the $20 \% \mathrm{NO}_{x}$ emission control experiment match well with VOC-limited areas indicated by the $\mathrm{NO}_{x} /$ VOCs and $\mathrm{H}_{2} \mathrm{O}_{2} / \mathrm{HNO}_{3}$ ratios (cf. Fig. 5e, f vs. Fig. 7a), suggesting that all the industrial regions considered here are VOC limited except Chongqing in the Sichuan Basin that is $\mathrm{NO}_{x}$ limited. The determination of $\mathrm{O}_{3}$ sensitivity regimes here is based on the $\mathrm{O}_{3}$ responses to decreasing anthropogenic $\mathrm{NO}_{x}$ and/or VOC emissions, and any potential impacts of changing BVOC emissions has not been assessed. Decreasing BVOC emissions may offset the increase in $\mathrm{O}_{3}$ levels due to decreased $\mathrm{NO}_{x}$ emissions for the NCP, the YRD, and the $\mathrm{PRD}$ and would make all regions more VOC limited. We note 

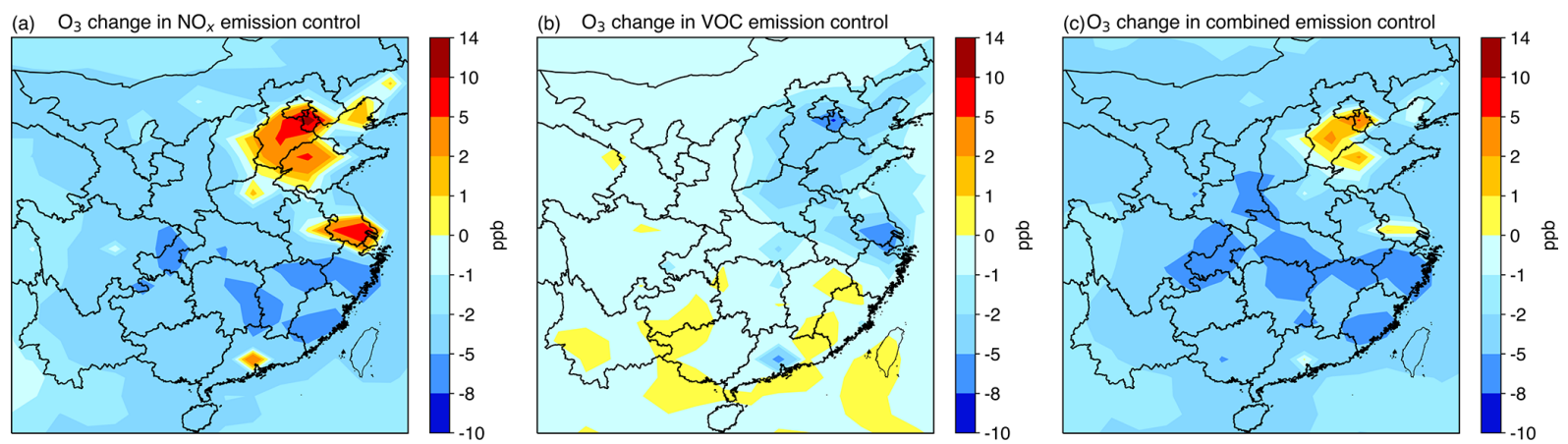

Figure 7. Spatial distributions of simulated surface daytime $\mathrm{O}_{3}$ concentration changes (ppb) for (a) the $20 \% \mathrm{NO}_{x}$ emission control, (b) the $20 \%$ VOC emission control, and (c) the $20 \%$ combined $\mathrm{NO}_{x}$ and VOC emission control compared to the present-day results in JJA, 2016, China.

Table 4. Simulated daytime mean $\mathrm{O}_{3}$ concentrations and changes (ppb) in $\mathrm{NO}_{x}$, VOC, and combined $\mathrm{NO}_{x}$ and $\mathrm{VOC}$ emission controls for the six industrial regions in JJA, 2016, China.

\begin{tabular}{lrrrrrrr}
\hline Region & Base & $\mathrm{NO}_{x}$ control & Change $(\%)$ & VOC control & Change $(\%)$ & $\mathrm{NO}_{x}+$ VOC control & Change $(\%)$ \\
\hline Beijing & 78.0 & 84.7 & $8.6 \%$ & 72.5 & $-7.0 \%$ & 79.7 & $2.2 \%$ \\
Shijiazhuang & 83.5 & 86.6 & $3.8 \%$ & 80.2 & $-3.9 \%$ & 84.6 & $1.4 \%$ \\
Shanghai & 70.1 & 77.8 & $11.0 \%$ & 63.1 & $-10.0 \%$ & 69.4 & $-1.0 \%$ \\
Nanjing & 66.8 & 72.4 & $8.5 \%$ & 61.4 & $-8.0 \%$ & 67.8 & $1.6 \%$ \\
Guangzhou & 60.2 & 64.8 & $7.6 \%$ & 53.8 & $-10.7 \%$ & 60.4 & $0.3 \%$ \\
Chongqing & 93.8 & 89.5 & $-4.6 \%$ & 92.5 & $-1.4 \%$ & 88.5 & $-5.6 \%$ \\
\hline
\end{tabular}

that our conclusion of $\mathrm{NO}_{x}$ limitation in Chongqing may be sensitive to our underestimation of $\mathrm{NO}_{2}$ levels (Sect. 3) and to the higher BVOC emissions in this region, both of which reduce the ratio of $\mathrm{NO}_{x}$ to $\mathrm{VOC}$ in the region (Table 3). However, satellite-observation-based studies have also suggested this region as one that is largely $\mathrm{NO}_{x}$ limited, in contrast to the heavily populated coastal regions (Wang et al., 2021).

In general, the greatest $\mathrm{O}_{3}$ increases in the $20 \% \mathrm{NO}_{x}$ control scenario occur in areas with high precursor concentrations. Shanghai shows the largest $\mathrm{O}_{3}$ increases $(11 \%)$ (Table 4) and has the highest underlying $\mathrm{NO}_{x}$ concentrations (Table 3). $\mathrm{O}_{3}$ increases in Beijing and Guangzhou are similar $(\sim 8 \%)$, possibly because of their similar $\mathrm{NO}_{x}$ concentrations. Shijiazhuang in the NCP shows the smallest $\mathrm{O}_{3}$ increase $(4 \%)$ because of its lower $\mathrm{NO}_{x}$ concentrations. In contrast, an $\mathrm{O}_{3}$ decrease of $4 \%$ is seen in Chongqing, which is $\mathrm{NO}_{x}$ limited. In the $20 \%$ VOC control scenario, the largest $\mathrm{O}_{3}$ decreases are simulated in Shanghai and Guangzhou $(-10 \%)$, while minimal $\mathrm{O}_{3}$ decreases $(-1 \%)$ are simulated in Chongqing. The simulated chemical environment in Chongqing is $\mathrm{NO}_{x}$ limited, and therefore the $\mathrm{O}_{3}$ changes are not sensitive to VOC emissions.

In addition to separate $20 \%$ reductions in $\mathrm{NO}_{x}$ and VOC emissions, we demonstrate the importance of combined $\mathrm{NO}_{x}$ and VOC emission controls to mitigate $\mathrm{O}_{3}$ pollution in VOClimited regions. This effectively offsets the higher levels of $\mathrm{O}_{3}$ that arise with $\mathrm{NO}_{x}$ emission reductions alone. The $\mathrm{O}_{3}$ increase in Shanghai is fully offset in the combined emission control $(-1 \%)$. While $\mathrm{O}_{3}$ increases still occur in the other VOC-limited regions, these increases are minimal $(<3 \%)$. Reducing both $\mathrm{NO}_{x}$ and VOC emissions decreases $\mathrm{O}_{3}$ levels in Chongqing by $6 \%$. Therefore, combined emission controls are necessary to efficiently mitigate $\mathrm{O}_{3}$ pollution in all these industrial regions, and VOC emission controls should be at least as stringent as $\mathrm{NO}_{x}$ emission controls to address rising $\mathrm{O}_{3}$ levels in these industrial regions.

\section{Effectiveness of emission controls in reducing surface $\mathrm{O}_{3}$ levels}

To provide a more complete exploration of the effectiveness of emission controls, we construct a response surface of summertime daytime $\mathrm{O}_{3}$ for each region to show the effect of changing $\mathrm{NO}_{x}$ and VOC emissions. We do this by performing a set of 64 model simulations with global anthropogenic $\mathrm{NO}_{x}$ and VOC emissions scaled independently over the range $0 \%-140 \%$ in increments of $20 \%$.

Figure 8 shows the magnitude and direction of $\mathrm{O}_{3}$ changes in the six regions as $\mathrm{NO}_{x}$ and $\mathrm{VOC}$ emissions change. For context, Fig. 8a also shows the simulated daytime $\mathrm{O}_{3}$ changes between 2013 and 2019 in the Beijing region, assuming that the emission changes observed between 2013 and 2016 continue at the same rate until 2019 (Cheng et al., 2019). We find that simulated $\mathrm{O}_{3}$ concentrations in Bei- 

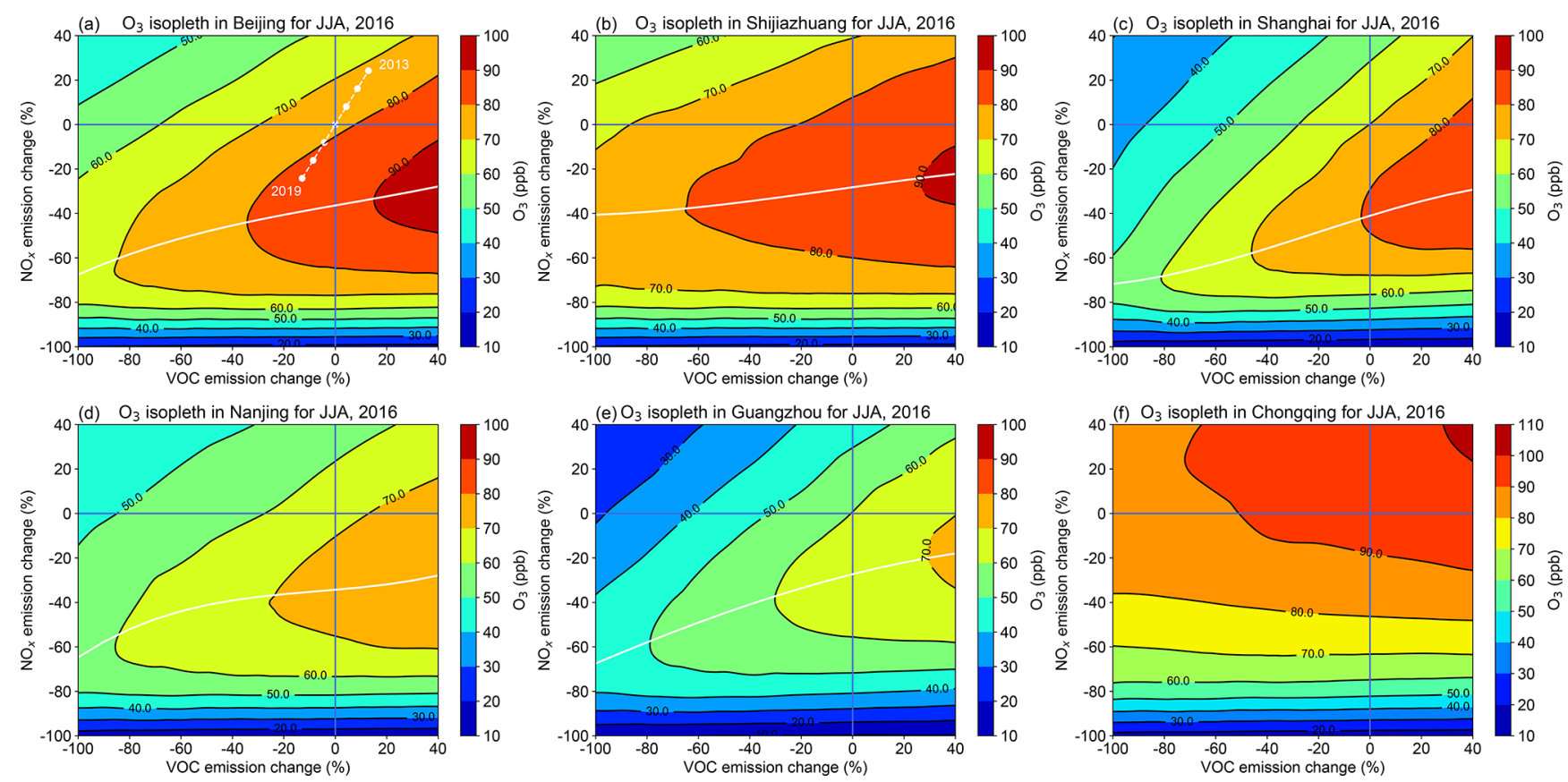

Figure 8. Simulated daytime surface $\mathrm{O}_{3}$ responses (ppb) to anthropogenic $\mathrm{NO}_{x}$ and $\mathrm{VOC}$ emission changes for the six industrial regions across China (a-f) in JJA, 2016. The intersection of the vertical and horizontal lines marks current $\mathrm{O}_{3}$ levels. White ridge lines mark the peak in $\mathrm{O}_{3}$ concentrations for given $\mathrm{VOC}$ emissions and show the approximate transition between VOC-limited (above the ridge) and $\mathrm{NO}_{x}$-limited (below the ridge) regimes. White dots in panel (a) represent simulated daytime $\mathrm{O}_{3}$ levels in the Beijing region in JJA between 2013 and 2019 following estimated $\mathrm{NO}_{x}$ and VOC emission changes.

jing increase from $71.6 \mathrm{ppb}$ in 2013 to $82.6 \mathrm{ppb}$ in 2019 , an increase of $1.8 \mathrm{ppbyr}^{-1}$. This is consistent with observed changes of $1.9 \mathrm{ppbyr}^{-1}$ over this period due to anthropogenic emission changes ( $\mathrm{Li}$ et al., 2020). The observed daytime $\mathrm{O}_{3}$ concentrations are $83 \mathrm{ppb}$ in the Beijing region in 2019. This demonstrates that the model captures not only the magnitude and diurnal pattern of $\mathrm{O}_{3}$ in summer 2016 well but also the observed $\mathrm{O}_{3}$ changes in recent years.

The patterns of $\mathrm{O}_{3}$ response seen in the VOC-limited regions (Fig. 8a-e) are similar, such that decreases in $\mathrm{NO}_{x}$ emissions from their current levels increase $\mathrm{O}_{3}$ concentrations. Large $\mathrm{O}_{3}$ increases occur in Shanghai and Beijing, highlighting that it is not beneficial to reduce $\mathrm{NO}_{x}$ emissions unless VOC emissions are also reduced. Large reductions $(\sim 40 \%)$ in $\mathrm{NO}_{x}$ emissions are required to shift the chemical environment from VOC limited to $\mathrm{NO}_{x}$ limited for these two regions. The large decrease in $\mathrm{O}_{3}$ in Shanghai and Guangzhou when reducing VOC emissions indicates that the efficiency in lowering $\mathrm{O}_{3}$ levels by decreasing VOC emissions is high in these regions. In contrast, the efficiency of VOC emissions alone in reducing $\mathrm{O}_{3}$ levels is lower in Shijiazhuang and Chongqing.

Figure 9 shows the $\mathrm{O}_{3}$ responses in each region to changes in $\mathrm{NO}_{x}$ emissions, $\mathrm{VOC}$ emissions, and combined $\mathrm{NO}_{x}$ and VOC emissions, which represent cross sections through the $\mathrm{O}_{3}$ response surfaces shown in Fig. 8. It is difficult to decrease $\mathrm{O}_{3}$ concentrations in Shanghai by reducing $\mathrm{NO}_{x}$ emissions alone because there is a steep rise in surface $\mathrm{O}_{3}$ $(\sim 15 \%)$ when $\mathrm{NO}_{x}$ emissions are reduced by $40 \%$ from the current state. Decreasing $\mathrm{O}_{3}$ from current levels requires reductions in $\mathrm{NO}_{x}$ emissions of more than $50 \%$ for Shijiazhuang and Guangzhou and more than $70 \%$ for Beijing, Shanghai and Nanjing. This suggests that mitigating poor $\mathrm{O}_{3}$ air quality in these VOC-limited regions through $\mathrm{NO}_{x}$ emission controls alone would require much greater reductions than the $21 \%$ reductions in $\mathrm{NO}_{x}$ emissions that are reported to have occurred in China from 2013 to 2017 (Zheng et al., 2018).

$\mathrm{O}_{3}$ responses to $\mathrm{VOC}$ emission changes are smaller and more linear than the responses seen for $\mathrm{NO}_{x}$ emissions changes (Fig. 9a, b). Reducing VOC emissions by $40 \%$ gives large decreases in $\mathrm{O}_{3}$ concentrations (20\%) in Shanghai and Guangzhou and smaller decreases $(<10 \%)$ in Shijiazhuang and Chongqing (Fig. 9b). Reductions in VOC emissions are key to reducing present-day $\mathrm{O}_{3}$ concentrations as they effectively offset the rising $\mathrm{O}_{3}$ levels due to decreasing $\mathrm{NO}_{x}$ emissions (Fig. 9c). Emission reductions of $50 \%$ or more are required to reduce $\mathrm{O}_{3}$ levels for all regions if controls on $\mathrm{NO}_{x}$ and VOC emissions are applied simultaneously.

To place our results in a wider global context, Fig. 10 shows summer daily mean surface $\mathrm{O}_{3}$ changes over different regions with high emissions in other parts of the world compared with those in China. We consider six major industrialised regions outside of China and select the model 


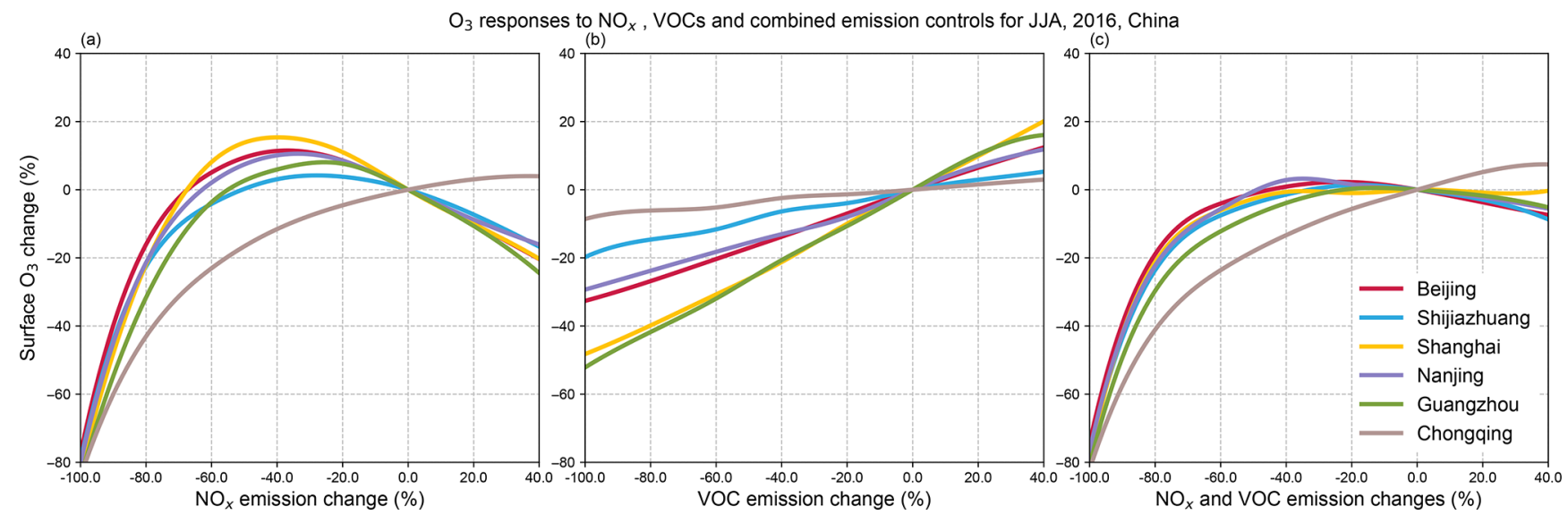

Figure 9. Simulated daytime surface $\mathrm{O}_{3}$ responses to changes in anthropogenic emissions of (a) $\mathrm{NO}_{x}$, (b) $\mathrm{VOC}_{\text {, and }}$ (c) combined $\mathrm{NO}_{x}$ and VOC emissions for the six industrial regions in JJA, 2016, China.

grid cell that is most closely co-located with the region. We note that proportional increases in summer daily mean $\mathrm{O}_{3}$ are larger than that of daytime $\mathrm{O}_{3}$ increases when $\mathrm{NO}_{x}$ emissions are reduced (see Fig. 9), principally because absolute $\mathrm{O}_{3}$ concentrations are smaller with the inclusion of nighttime conditions. We find that all selected high-emission regions across the globe outside of China are $\mathrm{NO}_{x}$ limited at the model resolution considered here, such that $\mathrm{NO}_{x}$ emission decreases yield regional $\mathrm{O}_{3}$ decreases. Current levels of $\mathrm{NO}_{x}$ emissions in these regions are considerably lower than for the industrial regions of China, reflecting the different $\mathrm{O}_{3}$ sensitivity regimes (Table 5). We note that these results apply to the wide urban regions considered here and that local $\mathrm{O}_{3}$ sensitivity in some parts of these regions may be different.

Reductions of both $\mathrm{NO}_{x}$ and VOC emissions substantially decrease $\mathrm{O}_{3}$ levels for these selected regions outside of China, and the magnitude of the $\mathrm{O}_{3}$ decreases are similar to those found for Chongqing (Fig. 10). Conversely, the magnitude of $\mathrm{O}_{3}$ decreases when reducing VOC emissions are smaller than all five VOC-limited regions in China. This indicates that $\mathrm{O}_{3}$ concentrations are less sensitive to VOC emissions in these other world regions due to their lower VOC emissions (Table 5).

Despite lower $\mathrm{NO}_{x}$ and VOC emissions in the regions outside of China, surface $\mathrm{O}_{3}$ concentrations, particularly in the Seoul and New York regions, are similar to those for China. This highlights that regional $\mathrm{O}_{3}$ levels also depend on background $\mathrm{O}_{3}$ concentrations, despite localised $\mathrm{NO}_{x}$ and VOC emissions that lead to different $\mathrm{O}_{3}$ production regimes. The $\mathrm{O}_{3}$ levels in European regions, e.g. London and Paris, are lowest, in accordance with the lowest $\mathrm{NO}_{x}$ and VOC emission levels. Overall, these results show that there are substantial differences in the efficiency of emission control scenarios to reduce surface $\mathrm{O}_{3}$ levels in different parts of the world. For many industrial regions of China, the extended regions are VOC limited, and hence reductions of VOC emissions
Table 5. Anthropogenic $\mathrm{NO}_{x}$ and VOC emissions $\left(\times e^{-10} \mathrm{~kg} \mathrm{~m}^{-2} \mathrm{~s}^{-1}\right)$ and summertime mean surface $\mathrm{O}_{3}$ concentrations $(\mathrm{ppb})$ in regions across the industrial regions of China and the globe. MEIC emissions of 2013 adjusted for 2016 are used for Chinese industrial regions. HTAP emissions of 2010 are used for other regions of the globe.

\begin{tabular}{lrrr}
\hline Region & $\mathrm{NO}_{x}$ emissions & VOC emissions & $\mathrm{O}_{3}$ conc. \\
\hline China & & & \\
\hline Beijing & 5.5 & 6.7 & 43.4 \\
Shijiazhuang & 4.2 & 4.6 & 47.6 \\
Shanghai & 7.4 & 9.6 & 34.4 \\
Nanjing & 6.9 & 8.1 & 35.9 \\
Guangzhou & 8.4 & 12.0 & 28.0 \\
Chongqing & 3.1 & 3.6 & 56.0 \\
\hline Global & & & \\
\hline Tokyo & & & \\
Seoul & 2.0 & 2.6 & 38.9 \\
New York & 1.5 & 2.1 & 45.5 \\
L.A. & 2.3 & 3.1 & 45.3 \\
London & 1.1 & 1.3 & 40.1 \\
Paris & 1.1 & 1.5 & 30.6 \\
\hline
\end{tabular}

are the key to reducing poor $\mathrm{O}_{3}$ air quality. For other regions selected in this study $\mathrm{NO}_{x}$ emission reductions are still pertinent to improving $\mathrm{O}_{3}$ pollution.

\section{Conclusions}

This study presents the application of the global chemistryclimate UKCA model with an improved gas-phase chemistry scheme including more reactive VOCs to simulate regional summertime $\mathrm{O}_{3}$ pollution across major industrialised regions in China for the first time. Differences in atmospheric chem- 


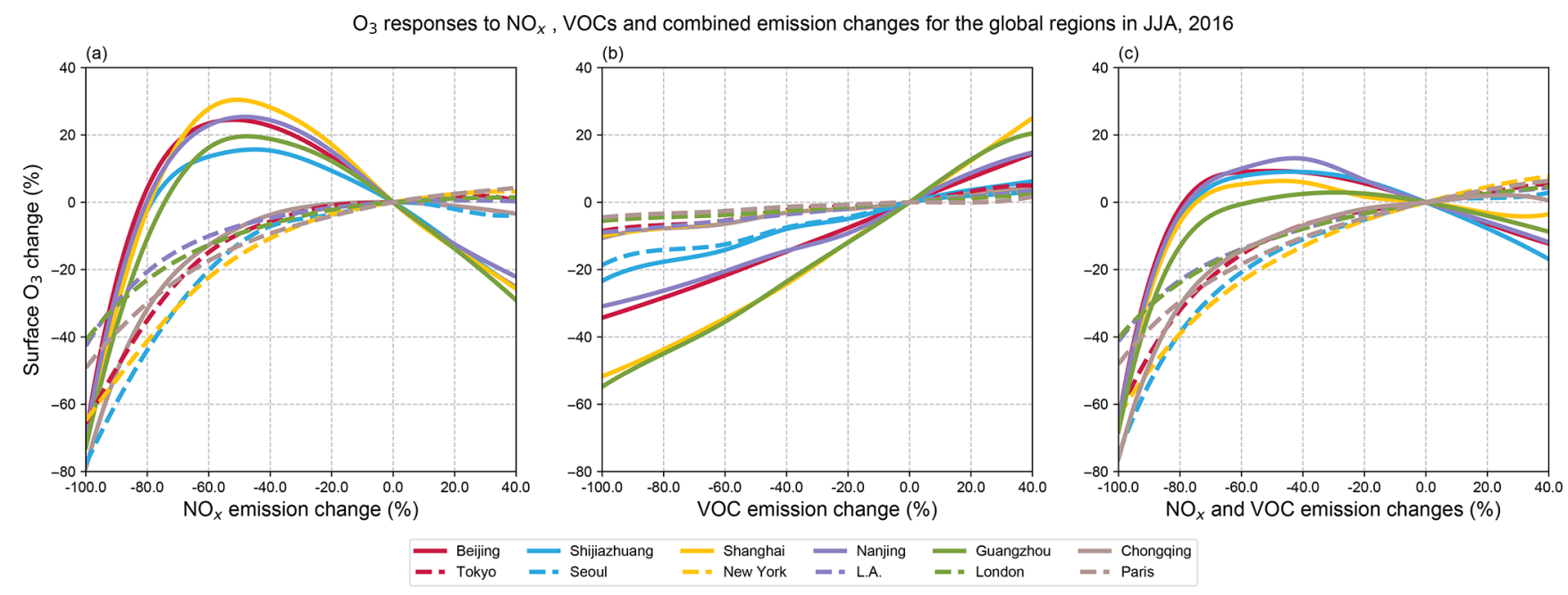

Figure 10. Simulated summer daily mean surface $\mathrm{O}_{3}$ responses to anthropogenic (a) $\mathrm{NO}_{x}$, (b) $\mathrm{VOC}$, and (c) combined $\mathrm{NO}_{x}$ and $\mathrm{VOC}$ emission changes in regions across the globe: Tokyo, Seoul, New York, L.A., London, Paris (dashed lines) and those in major industrial regions of China (solid lines) in JJA, 2016.

ical environments are investigated, and the effectiveness of different emission control strategies in reducing $\mathrm{O}_{3}$ concentrations is quantified. The model captures the magnitude, diurnal profiles and diurnal variation of $\mathrm{O}_{3}$ concentrations across most industrial regions well. We highlight that peak $\mathrm{O}_{3}$ concentrations can be captured well, indicating that $\mathrm{O}_{3}$ production can be effectively simulated with more highly active VOC oxidation environments for high-emission regions of China.

Simulated daytime $\mathrm{O}_{3}$ levels are highest on the North China Plain (Beijing and Shijiazhuang) and in the Sichuan Basin (Chongqing) and are lowest in the Pearl River Delta (Guangzhou). We find that there is a systematic bias in $\mathrm{O}_{3}$ throughout the diurnal cycle in Chongqing, reflecting the mountainous inland area that is inadequately captured by the topography in the model. The $\mathrm{O}_{3}$ production rates are highest in the Pearl River Delta compared to other regions. However, its much lower $\mathrm{O}_{3}$ levels reflect the importance of meteorological impacts in this coastal region. OPE values in these industrial regions are low, indicating that their high $\mathrm{O}_{3}$ levels are mainly caused by high precursor emissions. Both $\mathrm{O}_{3}$ sensitivity ratios we apply here $\left(\mathrm{NO}_{x} / \mathrm{VOCs}\right.$ and $\mathrm{H}_{2} \mathrm{O}_{2} / \mathrm{HNO}_{3}$ ) suggest that all the industrial regions except Chongqing are VOC limited. This study hence provides a broad assessment of the $\mathrm{O}_{3}$ sensitivities for these regions with implications for emission control strategies.

A set of simulations are performed with a range of $\mathrm{NO}_{x}$ and VOC emissions to construct $\mathrm{O}_{3}$ response surfaces to assess the impacts of different emission control strategies in different regions. Reducing $\mathrm{NO}_{x}$ emissions alone by $20 \%$ leads to a substantial $\mathrm{O}_{3}$ increase $(11 \%)$ in Shanghai. Reductions in VOC emissions alone of $20 \%$ produce the largest decrease $(-11 \%)$ in $\mathrm{O}_{3}$ levels in Shanghai and Guangzhou and the smallest decrease $(-1 \%)$ in Chongqing. We find that reducing $\mathrm{O}_{3}$ concentrations across all industrial regions of China would require more than $70 \%$ reductions if reducing $\mathrm{NO}_{x}$ emissions alone, and therefore VOC emission controls are important to reduce $\mathrm{O}_{3}$ levels. We also find that combined emission controls effectively offset high $\mathrm{O}_{3}$ levels that arise from reduced $\mathrm{NO}_{x}$ emissions alone. These responses are substantially different from those currently found in major highly populated regions in other parts of the world. The results show $\mathrm{NO}_{x}$-limited $\mathrm{O}_{3}$ production in these global areas, which also reflects the predominance of heavily populated VOC-limited areas across the industrial regions in China. Therefore, $\mathrm{O}_{3}$ pollution in the industrial regions of China should be treated as a regional issue, and regional VOC emission control strategies should be considered.

The new capabilities for simulating regional surface $\mathrm{O}_{3}$ pollution developed here will be helpful for future model studies to investigate the regional $\mathrm{O}_{3}$ impacts on climate. The magnitude of $\mathrm{O}_{3}$ changes over recent years in the Beijing region can be reproduced well. There remain model biases in regions with complex topography and high elevation - a common issue for global and regional models. Another source of uncertainty is the rapid change in anthropogenic emissions in recent years in China, which presents a particular challenge for inventory development. Recently, while $\mathrm{NO}_{x}$ emissions have been successfully reduced across many regions in China, changes in VOC emissions have been relatively small, and this has led to an increase in $\mathrm{O}_{3}$ concentrations in many regions. Regional VOC emission controls are hence urgently needed to maximise the effectiveness in reducing surface $\mathrm{O}_{3}$ pollution in China. 
Data availability. The data generated in this study are available upon request.

Author contributions. ZL, RD and OW designed the study. ZL, MH and FO'C set up the model. ZL ran model simulations and performed the analysis. ZL, RD and OW prepared the paper with contributions from all co-authors.

Competing interests. The authors declare that they have no conflict of interest.

Disclaimer. Publisher's note: Copernicus Publications remains neutral with regard to jurisdictional claims in published maps and institutional affiliations.

Acknowledgements. Zhenze Liu thanks the University of Edinburgh China Scholarship Council. Michael Hollaway, Oliver Wild and Ruth M. Doherty thank the Natural Environment Research Council (NERC) for funding under grants NE/N006925/1, NE/N006976/1 and NE/N006941/1. This work made use of computation resources on the Met Office and NERC joint supercomputer system (MONSooN) in the UK. Zhenze Liu thanks the UKCA community for help in the model set-up.

Financial support. This research has been supported by the Natural Environment Research Council (grant nos. NE/N006925/1, NE/N006976/1 and NE/N006941/1) and the China Scholarship Council (grant no. 201708060462).

Review statement. This paper was edited by Yugo Kanaya and reviewed by two anonymous referees.

\section{References}

André, J. C., Moor, G. D., Lacarrère, P., and Vachat, R. d.: Modeling the 24-Hour Evolution of the Mean and Turbulent Structures of the Planetary Boundary Layer, J. Atmos. Sci., 35, 1861-1883, 1978.

Archibald, A. T., O'Connor, F. M., Abraham, N. L., ArcherNicholls, S., Chipperfield, M. P., Dalvi, M., Folberth, G. A., Dennison, F., Dhomse, S. S., Griffiths, P. T., Hardacre, C., Hewitt, A. J., Hill, R. S., Johnson, C. E., Keeble, J., Köhler, M. O., Morgenstern, O., Mulcahy, J. P., Ordóñez, C., Pope, R. J., Rumbold, S. T., Russo, M. R., Savage, N. H., Sellar, A., Stringer, M., Turnock, S. T., Wild, O., and Zeng, G.: Description and evaluation of the UKCA stratosphere-troposphere chemistry scheme (StratTrop vn 1.0) implemented in UKESM1, Geosci. Model Dev., 13, 1223-1266, https://doi.org/10.5194/gmd-13-1223-2020, 2020.

Atkinson, R., Baulch, D. L., Cox, R. A., Crowley, J. N., Hampson, R. F., Hynes, R. G., Jenkin, M. E., Rossi, M. J., Troe, J., and IUPAC Subcommittee: Evaluated kinetic and photochemi- cal data for atmospheric chemistry: Volume II - gas phase reactions of organic species, Atmos. Chem. Phys., 6, 3625-4055, https://doi.org/10.5194/acp-6-3625-2006, 2006.

Bieser, J., Aulinge, A., Matthias, V., Quante, M., and van der Gon, H.: Vertical emission profiles for Europe based on plume rise calculations, Environ. Pollut., 159, 2935-2946, https://doi.org/10.1016/j.envpol.2011.04.030, 2011.

Biggart, M., Stocker, J., Doherty, R. M., Wild, O., Hollaway, M., Carruthers, D., Li, J., Zhang, Q., Wu, R., Kotthaus, S., Grimmond, S., Squires, F. A., Lee, J., and Shi, Z.: Streetscale air quality modelling for Beijing during a winter 2016 measurement campaign, Atmos. Chem. Phys., 20, 2755-2780, https://doi.org/10.5194/acp-20-2755-2020, 2020.

Cheng, J., Su, J., Cui, T., Li, X., Dong, X., Sun, F., Yang, Y., Tong, D., Zheng, Y., Li, Y., Li, J., Zhang, Q., and He, K.: Dominant role of emission reduction in $\mathrm{P}_{2.5}$ air quality improvement in Beijing during 2013-2017: a model-based decomposition analysis, Atmos. Chem. Phys., 19, 6125-6146, https://doi.org/10.5194/acp19-6125-2019, 2019.

Dee, D. P., Uppala, S. M., Simmons, A. J., Berrisford, P., Poli, P., Kobayashi, S., Andrae, U., Balmaseda, M. A., Balsamo, G., Bauer, P., Bechtold, P., Beljaars, A. C. M., van de Berg, I., Biblot, J., Bormann, N., Delsol, C., Dragani, R., Fuentes, M., Greer, A. J., Haimberger, L., Healy, S. B., Hersbach, H., Holm, E. V., Isaksen, L., Kallberg, P., Kohler, M., Matricardi, M., McNally, A. P., Mong-Sanz, B. M., Morcette, J.-J., Park, B.-K., Peubey, C., de Rosnay, P., Tavolato, C., Thepaut, J. N., and Vitart, F.: The ERAInterim reanalysis: Configuration and performance of the data assimilation system, Q. J. Roy. Meteorol. Soc., 137, 553-597, https://doi.org/10.1002/qj.828, 2011.

Fenech, S., Doherty, R. M., Heaviside, C., Vardoulakis, S., Macintyre, H. L., and O'Connor, F. M.: The influence of model spatial resolution on simulated ozone and fine particulate matter for Europe: implications for health impact assessments, Atmos. Chem. Phys., 18, 5765-5784, https://doi.org/10.5194/acp18-5765-2018, 2018.

Folberth, G. A., Hauglustaine, D. A., Lathière, J., and Brocheton, F.: Interactive chemistry in the Laboratoire de Météorologie Dynamique general circulation model: model description and impact analysis of biogenic hydrocarbons on tropospheric chemistry, Atmos. Chem. Phys., 6, 2273-2319, https://doi.org/10.5194/acp-6-2273-2006, 2006.

Gong, C. and Liao, H.: A typical weather pattern for ozone pollution events in North China, Atmos. Chem. Phys., 19, 13725-13740, https://doi.org/10.5194/acp-19-13725-2019, 2019.

Hewitt, H. T., Copsey, D., Culverwell, I. D., Harris, C. M., Hill, R. S. R., Keen, A. B., McLaren, A. J., and Hunke, E. C.: Design and implementation of the infrastructure of HadGEM3: the next-generation Met Office climate modelling system, Geosci. Model Dev., 4, 223-253, https://doi.org/10.5194/gmd-4-2232011, 2011.

Hodnebrog, O., Stordal, F., and Berntsen, T. K.: Does the resolution of megacity emissions impact large scale ozone?, Atmos. Environ., 45, 6852-6862, https://doi.org/10.1016/j.atmosenv.2011.01.012, 2011.

Horowitz, L. W., Liang, J. Y., Gardner, G. M., and Jacob, D. J.: Export of reactive nitrogen from North America during summertime: Sensitivity to hydrocarbon chemistry, J. Geophys. Res.- 
Atmos., 103, 13451-13476, https://doi.org/10.1029/97jd03142, 1998.

Janssens-Maenhout, G., Crippa, M., Guizzardi, D., Dentener, F., Muntean, M., Pouliot, G., Keating, T., Zhang, Q., Kurokawa, J., Wankmüller, R., Denier van der Gon, H., Kuenen, J. J. P., Klimont, Z., Frost, G., Darras, S., Koffi, B., and Li, M.: HTAP_v2.2: a mosaic of regional and global emission grid maps for 2008 and 2010 to study hemispheric transport of air pollution, Atmos. Chem. Phys., 15, 11411-11432, https://doi.org/10.5194/acp-15-11411-2015, 2015.

Jin, X. M. and Holloway, T.: Spatial and temporal variability of ozone sensitivity over China observed from the Ozone Monitoring Instrument, J. Geophys. Res.-Atmos., 120, 7229-7246, https://doi.org/10.1002/2015jd023250, 2015.

Kleinman, L. I., Daum, P. H., Lee, J. H., Lee, Y. N., Nunnermacker, L. J., Springston, S. R., Newman, L., WeinsteinLloyd, J., and Sillman, S.: Dependence of ozone production on NO and hydrocarbons in the troposphere, Geophys. Res. Lett., 24, 2299-2302, https://doi.org/10.1029/97gl02279, 1997.

Kleinman, L. I., Daum, P. H., Lee, Y. N., Nunnermacker, L. J., Springston, S. R., Weinstein-Lloyd, J., and Rudolph, J.: Ozone production efficiency in an urban area, J. Geophys. Res.-Atmos., 107, 4733, https://doi.org/10.1029/2002jd002529, 2002.

Kleinman, L. I., Daum, P. H., Lee, Y. N., Nunnermacker, L. J., Springston, S. R., Weinstein-Lloyd, J., and Rudolph, J.: A comparative study of ozone production in five U.S. metropolitan areas, J. Geophys. Res.-Atmos., 110, D02301, https://doi.org/10.1029/2004jd005096, 2005.

Li, K., Jacob, D. J., Liao, H., Shen, L., Zhang, Q., and Bates, K. H.: Anthropogenic drivers of 2013-2017 trends in summer surface ozone in China, P. Natl. Acad. Sci. USA, 116, 422-427, https://doi.org/10.1073/pnas.1812168116, 2019a.

Li, K., Jacob, D. J., Liao, H., Zhu, J., Shah, V., Shen, L., Bates, K. H., Zhang, Q., and Zhai, S. X.: A two-pollutant strategy for improving ozone and particulate air quality in China, Nat. Geosci., 12, 906-910, https://doi.org/10.1038/s41561-019-0464$\mathrm{x}, 2019 \mathrm{~b}$.

Li, K., Jacob, D. J., Shen, L., Lu, X., De Smedt, I., and Liao, H.: Increases in surface ozone pollution in China from 2013 to 2019: anthropogenic and meteorological influences, Atmos. Chem. Phys., 20, 11423-11433, https://doi.org/10.5194/acp-2011423-2020, 2020.

Li, L. Y., Chen, Y., and Xie, S. D.: Spatio-temporal variation of biogenic volatile organic compounds emissions in China, Environ. Pollut., 182, 157-168, https://doi.org/10.1016/j.envpol.2013.06.042, 2013.

Li, M., Zhang, Q., Kurokawa, J.-I., Woo, J.-H., He, K., Lu, Z., Ohara, T., Song, Y., Streets, D. G., Carmichael, G. R., Cheng, Y., Hong, C., Huo, H., Jiang, X., Kang, S., Liu, F., Su, H., and Zheng, B.: MIX: a mosaic Asian anthropogenic emission inventory under the international collaboration framework of the MICS-Asia and HTAP, Atmos. Chem. Phys., 17, 935-963, https://doi.org/10.5194/acp-17-935-2017, 2017.

Li, M., Liu, H., Geng, G. N., Hong, C. P., Liu, F., Song, Y., Tong, D., Zheng, B., Cui, H. Y., Man, H. Y., Zhang, Q., and He, K. B.: Corrigendum to Anthropogenic emission inventories in China: a review, Nat. Sci. Rev., 5, 603-603, https://doi.org/10.1093/nsr/nwy044, 2018.
Li, S., Wang, T. J., Huang, X., Pu, X., Li, M. M., Chen, P. L., Yang, X. Q., and Wang, M. H.: Impact of East Asian Summer Monsoon on Surface Ozone Pattern in China, J. Geophys. Res.-Atmos., 123, 1401-1411, https://doi.org/10.1002/2017jd027190, 2018.

Liu, H. L., Zhang, M. G., and Han, X.: A review of surface ozone source apportionment in China, Atmos. Ocean. Sci. Lett., 13, 470-484, https://doi.org/10.1080/16742834.2020.1768025, 2020.

Liu, S. C., Trainer, M., Fehsenfeld, F. C., Parrish, D. D., Williams, E. J., Fahey, D. W., Hubler, G., and Murphy, P. C.: Ozone production in the rural troposphere and the implications for regional and global ozone distributions, J. Geophys. Res.-Atmos., 92, 41914207, https://doi.org/10.1029/JD092iD04p04191, 1987.

Liu, X. H., Zhang, Y., Xing, J., Zhang, Q. A., Wang, K., Streets, D. G., Jang, C., Wang, W. X., and Hao, J. M.: Understanding of regional air pollution over China using CMAQ, part II. Process analysis and sensitivity of ozone and particulate matter to precursor emissions, Atmos. Environ., 44, 3719-3727, https://doi.org/10.1016/j.atmosenv.2010.03.036, 2010.

Liu, Y. and Wang, T.: Worsening urban ozone pollution in China from 2013 to 2017 - Part 1: The complex and varying roles of meteorology, Atmos. Chem. Phys., 20, 6305-6321, https://doi.org/10.5194/acp-20-6305-2020, 2020.

Lowe, D., Archer-Nicholls, S., Morgan, W., Allan, J., Utembe, S., Ouyang, B., Aruffo, E., Le Breton, M., Zaveri, R. A., Di Carlo, P., Percival, C., Coe, H., Jones, R., and McFiggans, G.: WRF-Chem model predictions of the regional impacts of N2O5 heterogeneous processes on night-time chemistry over north-western Europe, Atmos. Chem. Phys., 15, 1385-1409, https://doi.org/10.5194/acp-15-1385-2015, 2015.

Lu, H. X., Lyu, X. P., Cheng, H. R., Ling, Z. H., and Guo, H.: Overview on the spatial-temporal characteristics of the ozone formation regime in China, Environ. Sci.-Proc. Imp., 21, 916929, https://doi.org/10.1039/c9em00098d, 2019.

Lu, X., Hong, J. Y., Zhang, L., Cooper, O. R., Schultz, M. G., Xu, X. B., Wang, T., Gao, M., Zhao, Y. H., and Zhang, Y. H.: Severe Surface Ozone Pollution in China: A Global Perspective, Environ. Sci. Technol. Lett., 5, 487-494, https://doi.org/10.1021/acs.estlett.8b00366, 2018.

Lu, X., Zhang, L., Chen, Y., Zhou, M., Zheng, B., Li, K., Liu, Y., Lin, J., Fu, T.-M., and Zhang, Q.: Exploring 2016-2017 surface ozone pollution over China: source contributions and meteorological influences, Atmos. Chem. Phys., 19, 8339-8361, https://doi.org/10.5194/acp-19-8339-2019, 2019.

Mailler, S., Khvorostyanov, D., and Menut, L.: Impact of the vertical emission profiles on background gas-phase pollution simulated from the EMEP emissions over Europe, Atmos. Chem. Phys., 13, 5987-5998, https://doi.org/10.5194/acp-135987-2013, 2013.

Mann, G. W., Carslaw, K. S., Spracklen, D. V., Ridley, D. A., Manktelow, P. T., Chipperfield, M. P., Pickering, S. J., and Johnson, C. E.: Description and evaluation of GLOMAP-mode: a modal global aerosol microphysics model for the UKCA composition-climate model, Geosci. Model Dev., 3, 519-551, https://doi.org/10.5194/gmd-3-519-2010, 2010.

Mertens, M., Kerkweg, A., Grewe, V., Jöckel, P., and Sausen, R.: Are contributions of emissions to ozone a matter of scale? - a study using MECO(n) (MESSy v2.50), Geosci. Model Dev., 13, 363-383, https://doi.org/10.5194/gmd-13-363-2020, 2020. 
Monks, P. S., Archibald, A. T., Colette, A., Cooper, O., Coyle, M., Derwent, R., Fowler, D., Granier, C., Law, K. S., Mills, G. E., Stevenson, D. S., Tarasova, O., Thouret, V., von Schneidemesser, E., Sommariva, R., Wild, O., and Williams, M. L.: Tropospheric ozone and its precursors from the urban to the global scale from air quality to short-lived climate forcer, Atmos. Chem. Phys., 15, 8889-8973, https://doi.org/10.5194/acp-15-8889-2015, 2015.

Neu, J. L., Prather, M. J., and Penner, J. E.: Global atmospheric chemistry: Integrating over fractional cloud cover, J. Geophys. Res.-Atmos., 112, D11306, https://doi.org/10.1029/2006jd008007, 2007.

O’Connor, F. M., Johnson, C. E., Morgenstern, O., Abraham, N. L., Braesicke, P., Dalvi, M., Folberth, G. A., Sanderson, M. G., Telford, P. J., Voulgarakis, A., Young, P. J., Zeng, G., Collins, W. J., and Pyle, J. A.: Evaluation of the new UKCA climatecomposition model - Part 2: The Troposphere, Geosci. Model Dev., 7, 41-91, https://doi.org/10.5194/gmd-7-41-2014, 2014.

Pacifico, F., Harrison, S. P., Jones, C. D., Arneth, A., Sitch, S., Weedon, G. P., Barkley, M. P., Palmer, P. I., Serça, D., Potosnak, M., Fu, T.-M., Goldstein, A., Bai, J., and Schurgers, G.: Evaluation of a photosynthesis-based biogenic isoprene emission scheme in JULES and simulation of isoprene emissions under presentday climate conditions, Atmos. Chem. Phys., 11, 4371-4389, https://doi.org/10.5194/acp-11-4371-2011, 2011.

Petersen, A. K., Brasseur, G. P., Bouarar, I., Flemming, J., Gauss, M., Jiang, F., Kouznetsov, R., Kranenburg, R., Mijling, B., Peuch, V.-H., Pommier, M., Segers, A., Sofiev, M., Timmermans, R., van der A, R., Walters, S., Xie, Y., Xu, J., and Zhou, G.: Ensemble forecasts of air quality in eastern China - Part 2: Evaluation of the MarcoPolo-Panda prediction system, version 1, Geosci. Model Dev., 12, 1241-1266, https://doi.org/10.5194/gmd-12-1241-2019, 2019.

Reynolds, R. W., Smith, T. M., Liu, C., Chelton, D. B., Casey, K. S., and Schlax, M. G.: Daily high-resolution-blended analyses for sea surface temperature, J. Climate, 20, 5473-5496, https://doi.org/10.1175/2007jcli1824.1, 2007.

Sellar, A. A., Jones, C. G., Mulcahy, J. P., Tang, Y. M., Yool, A., Wiltshire, A., O'Connor, F. M., Stringer, M., Hill, R., Palmieri, J., Woodward, S., de Mora, L., Kuhlbrodt, T., Rumbold, S. T., Kelley, D. I., Ellis, R., Johnson, C. E., Walton, J., Abraham, N. L., Andrews, M. B., Andrews, T., Archibald, A. T., Berthou, S., Burke, E., Blockley, E., Carslaw, K., Dalvi, M., Edwards, J., Folberth, G. A., Gedney, N., Griffiths, P. T., Harper, A. B., Hendry, M. A., Hewitt, A. J., Johnson, B., Jones, A., Jones, C. D., Keeble, J., Liddicoat, S., Morgenstern, O., Parker, R. J., Predoi, V., Robertson, E., Siahaan, A., Smith, R. S., Swaminathan, R., Woodhouse, M. T., Zeng, G., and Zerroukat, M.: UKESM1: Description and Evaluation of the UK Earth System Model, J. Adv. Model. Earth Sy., 11, 4513-4558, https://doi.org/10.1029/2019ms001739, 2019.

Shi, Z., Huang, L., Li, J., Ying, Q., Zhang, H., and Hu, J.: Sensitivity analysis of the surface ozone and fine particulate matter to meteorological parameters in China, Atmos. Chem. Phys., 20, 1345513466, https://doi.org/10.5194/acp-20-13455-2020, 2020.

Sillman, S., Logan, J. A., and Wofsy, S. C.: The sensitivity of ozone to nitrogen-oxides and hydrocarbons in regional ozone episodes, J. Geophys. Res.-Atmos., 95, 1837-1851, https://doi.org/10.1029/JD095iD02p01837, 1990.
Sillman, S.: The use of $\mathrm{NO}_{y}, \mathrm{H}_{2} \mathrm{O}_{2}$, and $\mathrm{HNO}_{3}$ as indicators for ozone- $\mathrm{NO}_{x}$-hydrocarbon sensitivity in urban locations, J. Geophys. Res.-Atmos., 100, 14175-14188, https://doi.org/10.1029/94jd02953, 1995.

Sillman, S.: The relation between ozone, $\mathrm{NO}_{x}$ and hydrocarbons in urban and polluted rural environments, Atmos. Environ., 33, 1821-1845, https://doi.org/10.1016/s1352-2310(98)003458, 1999.

Sillman, S. and West, J. J.: Reactive nitrogen in Mexico City and its relation to ozone-precursor sensitivity: results from photochemical models, Atmos. Chem. Phys., 9, 3477-3489, https://doi.org/10.5194/acp-9-3477-2009, 2009.

Silver, B., Reddington, C. L., Arnold, S. R., and Spracklen, D. V.: Substantial changes in air pollution across China during 2015-2017, Environ. Res. Lett., 13, 114012, https://doi.org/10.1088/1748-9326/aae718, 2018.

Sindelarova, K., Granier, C., Bouarar, I., Guenther, A., Tilmes, S., Stavrakou, T., Müller, J.-F., Kuhn, U., Stefani, P., and Knorr, W.: Global data set of biogenic VOC emissions calculated by the MEGAN model over the last 30 years, Atmos. Chem. Phys., 14, 9317-9341, https://doi.org/10.5194/acp-14-9317-2014, 2014.

Stock, Z. S., Russo, M. R., and Pyle, J. A.: Representing ozone extremes in European megacities: the importance of resolution in a global chemistry climate model, Atmos. Chem. Phys., 14, 3899-3912, https://doi.org/10.5194/acp-14-3899-2014, 2014.

Su, R., Lu, K. D., Yu, J. Y., Tan, Z. F., Jiang, M. Q., Li, J., Xie, S. D., Wu, Y. S., Zeng, L. M., Zhai, C. Z., and Zhang, Y. H.: Exploration of the formation mechanism and source attribution of ambient ozone in Chongqing with an observation-based model, Sci. China-Earth Sci., 61, 23-32, https://doi.org/10.1007/s11430017-9104-9, 2018.

Tan, Z., Lu, K., Jiang, M., Su, R., Wang, H., Lou, S., Fu, Q., Zhai, C., Tan, Q., Yue, D., Chen, D., Wang, Z., Xie, S., Zeng, L., and Zhang, Y.: Daytime atmospheric oxidation capacity in four Chinese megacities during the photochemically polluted season: a case study based on box model simulation, Atmos. Chem. Phys., 19, 3493-3513, https://doi.org/10.5194/acp-193493-2019, 2019.

Tham, Y. J., Wang, Z., Li, Q., Wang, W., Wang, X., Lu, K., Ma, N., Yan, C., Kecorius, S., Wiedensohler, A., Zhang, Y., and Wang, T.: Heterogeneous $\mathrm{N}_{2} \mathrm{O}_{5}$ uptake coefficient and production yield of $\mathrm{CINO} 2$ in polluted northern China: roles of aerosol water content and chemical composition, Atmos. Chem. Phys., 18, 1315513171, https://doi.org/10.5194/acp-18-13155-2018, 2018.

Thornton, J. A., Wooldridge, P. J., Cohen, R. C., Martinez, M., Harder, H., Brune, W. H., Williams, E. J., Roberts, J. M., Fehsenfeld, F. C., Hall, S. R., Shetter, R. E., Wert, B. P., and Fried, A.: Ozone production rates as a function of NOx abundances and $\mathrm{HO}_{x}$ production rates in the Nashville urban plume, J. Geophys. Res.-Atmos., 107, ACH 7-1-ACH 7-17, https://doi.org/10.1029/2001jd000932, 2002.

Valari, M. and Menut, L.: Does an Increase in Air Quality Models' Resolution Bring Surface Ozone Concentrations Closer to Reality?, J. Atmos. Ocean. Tech., 25, 1955-1968, https://doi.org/10.1175/2008jtecha1123.1, 2008.

van der Werf, G. R., Randerson, J. T., Giglio, L., Collatz, G. J., Mu, M., Kasibhatla, P. S., Morton, D. C., DeFries, R. S., Jin, Y., and van Leeuwen, T. T.: Global fire emissions and the contribution of deforestation, savanna, forest, agricultural, and 
peat fires (1997-2009), Atmos. Chem. Phys., 10, 11707-11735, https://doi.org/10.5194/acp-10-11707-2010, 2010.

von Schneidemesser, E., Monks, P. S., Allan, J. D., Bruhwiler, L., Forster, P., Fowler, D., Lauer, A., Morgan, W. T., Paasonen, P., Righi, M., Sindelarova, K., and Sutton, M. A.: Chemistry and the Linkages between Air Quality and Climate Change, Chem. Rev., 115, 3856-3897, https://doi.org/10.1021/acs.chemrev.5b00089, 2015.

Walters, D., Baran, A. J., Boutle, I., Brooks, M., Earnshaw, P., Edwards, J., Furtado, K., Hill, P., Lock, A., Manners, J., Morcrette, C., Mulcahy, J., Sanchez, C., Smith, C., Stratton, R., Tennant, W., Tomassini, L., Van Weverberg, K., Vosper, S., Willett, M., Browse, J., Bushell, A., Carslaw, K., Dalvi, M., Essery, R., Gedney, N., Hardiman, S., Johnson, B., Johnson, C., Jones, A., Jones, C., Mann, G., Milton, S., Rumbold, H., Sellar, A., Ujiie, M., Whitall, M., Williams, K., and Zerroukat, M.: The Met Office Unified Model Global Atmosphere 7.0/7.1 and JULES Global Land 7.0 configurations, Geosci. Model Dev., 12, 1909-1963, https://doi.org/10.5194/gmd-12-1909-2019, 2019.

Wang, J. H., Ge, B. Z., and Wang, Z. F.: Ozone Production Efficiency in Highly Polluted Environments, Curr. Pollut. Rep., 4, 198-207, https://doi.org/10.1007/s40726-018-0093-9, 2018.

Wang, N., Lyu, X. P., Deng, X. J., Huang, X., Jiang, F., and Ding, A. J.: Aggravating $\mathrm{O}_{3}$ pollution due to $\mathrm{NO}_{x}$ emission control in eastern China, Sci. Total Environ., 677, 732-744, https://doi.org/10.1016/j.scitotenv.2019.04.388, 2019.

Wang, T., Xue, L. K., Brimblecombe, P., Lam, Y. F., Li, L., and Zhang, L.: Ozone pollution in China: A review of concentrations, meteorological influences, chemical precursors, and effects, Sci. Total Environ., 575, 1582-1596, https://doi.org/10.1016/j.scitotenv.2016.10.081, 2017.

Wang, W., van der A, R., Ding, J., van Weele, M., and Cheng, T.: Spatial and temporal changes of the ozone sensitivity in China based on satellite and ground-based observations, Atmos. Chem. Phys., 21, 7253-7269, https://doi.org/10.5194/acp21-7253-2021, 2021.

Wild, O. and Prather, M. J.: Global tropospheric ozone modeling: Quantifying errors due to grid resolution, J. Geophys. Res.Atmos., 111, D11305, https://doi.org/10.1029/2005jd006605, 2006.
Wu, R. R. and Xie, S. D.: Spatial Distribution of Ozone Formation in China Derived from Emissions of Speciated Volatile Organic Compounds, Environ. Sci. Technol., 51, 2574-2583, https://doi.org/10.1021/acs.est.6b03634, 2017.

Xing, J., Ding, D., Wang, S., Dong, Z., Kelly, J. T., Jang, C., Zhu, Y., and Hao, J.: Development and application of observable response indicators for design of an effective ozone and fine-particle pollution control strategy in China, Atmos. Chem. Phys., 19, 13627 13646, https://doi.org/10.5194/acp-19-13627-2019, 2019.

Young, P. J., Naik, V., Fiore, A. M., Gaudel, A., Guo, J., Lin, M. Y., Neu, J. L., Parrish, D. D., Rieder, H. E., Schnell, J. L., Tilmes, S., Wild, O., Zhang, L., Ziemke, J., Brandt, J., Delcloo, A., Doherty, R. M., Geels, C., Hegglin, M. I., Hu, L., Im, U., Kumar, R., Luhar, A., Murray, L., Plummer, D., Rodriguez, J., Saiz-Lopez, A., Schultz, M. G., Woodhouse, M. T., and Zeng, G.: Tropospheric Ozone Assessment Report: Assessment of global-scale model performance for global and regional ozone distributions, variability, and trends, Elementa, 6, 10, https://doi.org/10.1525/elementa.265, 2018.

Zhao, C., Wang, Y. H., Yang, Q., Fu, R., Cunnold, D., and Choi, Y.: Impact of East Asian summer monsoon on the air quality over China: View from space, J. Geophys. Res.-Atmos., 115, D09301, https://doi.org/10.1029/2009jd012745, 2010.

Zhao, Y. H., Zhang, L., Zhou, M., Chen, D., Lu, X., Tao, W., Liu, J. F., Tian, H., Ma, Y. P., and Fu, T. M.: Influences of planetary boundary layer mixing parameterization on summertime surface ozone concentration and dry deposition over North China, Atmos. Environ., 218, 116950, https://doi.org/10.1016/j.atmosenv.2019.116950, 2019.

Zheng, B., Tong, D., Li, M., Liu, F., Hong, C., Geng, G., Li, H., Li, X., Peng, L., Qi, J., Yan, L., Zhang, Y., Zhao, H., Zheng, Y., He, K., and Zhang, Q.: Trends in China's anthropogenic emissions since 2010 as the consequence of clean air actions, Atmos. Chem. Phys., 18, 14095-14111, https://doi.org/10.5194/acp-18-140952018, 2018. 